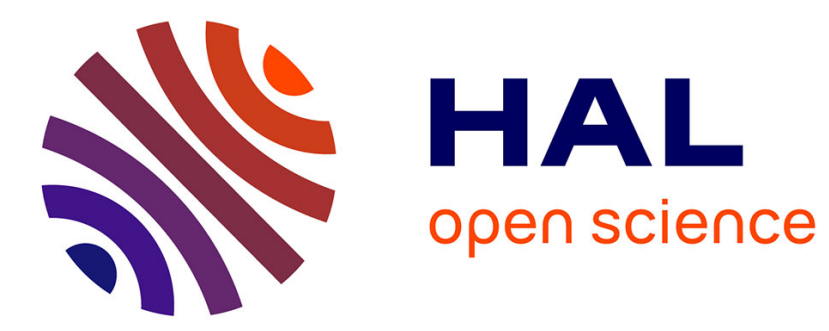

\title{
A Career in Catalysis: Odile Eisenstein
}

David Balcells, Eric Clot, Stuart Macgregor, Feliu Maseras, Lionel Perrin

\section{To cite this version:}

David Balcells, Eric Clot, Stuart Macgregor, Feliu Maseras, Lionel Perrin. A Career in Catalysis: Odile Eisenstein. ACS Catalysis, 2019, 9 (11), pp.10375-10388. 10.1021/acscatal.9b02498 . hal-03006418

\section{HAL Id: hal-03006418 https://hal.science/hal-03006418}

Submitted on 16 Nov 2020

HAL is a multi-disciplinary open access archive for the deposit and dissemination of scientific research documents, whether they are published or not. The documents may come from teaching and research institutions in France or abroad, or from public or private research centers.
L'archive ouverte pluridisciplinaire HAL, est destinée au dépôt et à la diffusion de documents scientifiques de niveau recherche, publiés ou non, émanant des établissements d'enseignement et de recherche français ou étrangers, des laboratoires publics ou privés. 


\title{
A Career in Catalysis: Odile Eisenstein
}

\author{
David Balcells, ${ }^{\dagger}$ Eric Clot,,${ }^{\ddagger}$ Stuart A. Macgregor,${ }^{\S}$ Feliu Maseras ${ }^{\prime \prime, *}$ Lionel Perrin ${ }^{\natural}$ \\ $\dagger$ Hylleraas Centre for Quantum Molecular Sciences, Department of Chemistry, University of \\ Oslo, P.O. Box 1033, Blindern, Oslo 0315, Norway \\ † IGCM, Univ. Montpellier, CNRS, ENSCM, Montpellier, France \\ $\S$ Institute of Chemical Sciences, Heriot-Watt University, Edinburgh EH14 4AS, United \\ Kingdom \\ II Institute of Chemical Research of Catalonia (ICIQ), The Barcelona Institute of Science and \\ Technology, Avgda. Països Catalans, 16, 43007 Tarragona, Catalonia, Spain . \\ I Université de Lyon, Université Claude Bernard Lyon 1, CPE Lyon, INSA Lyon, ICBMS, \\ CNRS UMR 5246, Equipe ITEMM, Bât Lederer, 1 rue V. Grignard, 69622 Villeurbanne, France
}

\begin{abstract}
On the occasion of Professor Odile Eisenstein's 70th birthday and her stepping down as Associate Editor of ACS Catalysis, we reflect on and highlight her distinguished career in computational chemistry and homogeneous catalysis. In this Account we present selected examples of her early work on the computational understanding of transition metal complexes, the evolution of the field towards the quantitative reproduction of these systems, with a final focus on her specific contributions to important catalytic processes including olefin metathesis, $\sigma$-bond metathesis, and catalytic oxidations.
\end{abstract}

KEYWORDS: molecular orbitals, DFT, dihydrogen complexes, olefin metathesis, $\sigma$-bond metathesis, catalytic oxidations 


\section{Introduction}

Many areas of catalysis were firmly established long decades ago. They have progressed through expansion and refinement, and a number of them have undoubtedly reached the highest pinnacles of success in recent years. In contrast, the emergence of computational homogeneous catalysis is a more recent phenomenon, this field only beginning to be established in its own right in the late 1990s. Its development required the availability of sufficiently powerful computers, and of the methods that would allow their efficient use. But it also required skilled computational chemists who were able to see the possibilities of the field and had both a technical understanding of calculations and a deep comprehension of the problems that were of interest to experimental chemists. Without a doubt, one of these key pioneers in computational homogeneous catalysis has been Odile Eisenstein. She has been instrumental in creating the current prominence of the field, which is thriving both among dedicated theoretical/computational chemists and among those experimental chemists who make use of calculations to inform their work.

Odile Eisenstein completed her Ph.D. in chemistry in 1977 at the Université de Paris-Sud under the supervision of Nguyen Trong Anh and Lionel Salem. After post-doctoral appointments with Jack D. Dunitz at ETH Zürich and Roald Hoffmann at Cornell University, she began her independent career at the University of Michigan in 1982. She returned to France and the Université de Paris-Sud in 1986, and moved to the Université de Montpellier in 1996, first as founder and director of the Laboratoire de Structure et Dynamique des Systèmes Moléculaires et Solide, and latterly as director of the Chimie Théorique, Méthodologies, Modélisations group. Since 2014 Odile has retained a base in Montpellier as a CNRS Emeritus Distinguished Research 
Director and she also holds an adjunct professorship at University of Oslo. Throughout her career Odile has held several visiting and adjunct professorships and her accomplishments have been recognized by numerous prizes, among them the Medaille d'Argent du CNRS in 1994 and the ACS Award in Organometallic Chemistry in 2009. In 2013 she became the first woman to be elected to the scientific division of the prestigious Académie des Sciences and in 2017 she became member of the Légion d'Honneur, the highest accolade in French society. Odile has also made substantial contributions to the chemical community, as the long serving editor-in-chief of the New Journal of Chemistry, and, in recent years, as Associate Editor of ACS Catalysis.

We are ready to admit that the first years of Odile's research were not in transition metal catalysis. At that time there was not such a thing as computational homogeneous catalysis! Odile's initial work was indeed in computational organic chemistry, and it was already highly impactful, as her $\mathrm{PhD}$ work on the rationalization of the Felkin-Anh model for asymmetric induction is currently taught in undergraduate courses. ${ }^{1}$ Although maybe not in this very early work, some of Odile's early publications contain the seeds to her subsequent contributions in catalysis, and because of this we have decided to include them in this Account. Odile was among the first to analyze theoretically the structure and properties of model transition metal complexes, and she also played a leading role in the transition to the use of real systems, and to the calculation of free energy profiles which are the bread-and-butter of modern computational homogeneous catalysis. We will summarize below a representative set of her contributions. An exhaustive review of all of them would take too much space and is outside of the scope of the current Account.

Before entering the details of the research we would also like to highlight the personal approach that Odile Eisenstein has brought to the field, and which has also been deeply 
influential. Odile has proved time and again that computational chemistry is something that must be of use to experimental chemists, and this has been particularly fruitful in the field of computational homogeneous catalysis. Odile Eisenstein has mentored a number of computational chemists (including the authors of this Account), and has created a school of activity that is defined by close collaboration and dialogue with experimental chemists. In doing so she has convinced skeptics within the catalysis community and brought computational chemistry to the prominent position that it enjoys today, and one that seems likely only to become more significant in the future.

\section{Transition Metal Dihydrogen and Hydride Complexes}

In the 1980s the ability to apply computational methods to study the reactivity of transition metal complexes was still very much in its infancy. Ab initio methods were restricted to the HartreeFock (HF) level with small basis sets, automatic geometry optimisation algorithms and electrostatic core potentials were only just beginning to be implemented, and density functional theory (DFT) was still to emerge as the ubiquitous tool it is today. However, molecular orbitals (MOs) were available in the ' 80 s and in the Extended Hückel Theory (EHT) there was a very efficient way of generating them. Odile's contributions centred around the design of computational experiments that, while recognizing the methodological limitations, used EHT to understand a range of specific structure and bonding problems and then to add value by generalising this insight through guiding principles such as the Isolobal Analogy.

The structural characterisation of $\mathrm{W}(\mathrm{CO})_{3}(\mathrm{P} P r)_{2}\left(\eta^{2}-\mathrm{H}_{2}\right)$, the first dihydrogen $\sigma$-complex, by Kubas in $1984^{2}$ led to intense activity among theoreticians to understand the structure and bonding of this new class of what are now known as $\sigma$-complexes. Working with Yves Jean, in 1986 Odile published a paper that explored the $\mathrm{M}-\left(\eta^{2}-\mathrm{H}_{2}\right)$ dihydrogen/M(H) 2 dihydride dichotomy, ${ }^{3}$ commenting in the introduction that "The nature of $\mathrm{H}-\mathrm{H}$ bond interaction with a metal is a fundamental question because of its relevance to homogeneous catalysis." This paper considered the interaction of $\mathrm{H}_{2}$ with a series of model $\mathrm{d}^{6}\left\{\mathrm{ML}_{5}\right\}$ fragments, where $\mathrm{M}=\mathrm{Cr}, \mathrm{W}$, 
$\mathrm{Fe}^{2+}$ and with $\mathrm{L}=\mathrm{H}^{-}$or $\mathrm{CO}$ (representing generic $\sigma$-donor and $\pi$-acceptor ligands respectively). The $\mathrm{H}_{2}$ ligand binds through a combination of $\sigma$-donation from the occupied $\sigma_{\mathrm{g}}\left(\mathrm{H}_{2}\right)(\mathbf{1 a})$ and $\pi$ back-donation from an occupied $d_{\pi}$ orbital on the $\mathrm{ML}_{5}$ fragment into $\sigma_{u} *\left(\mathrm{H}_{2}\right)(\mathbf{1 b})$. Enhanced back-donation was identified as the key factor in cleaving the $\mathrm{H}-\mathrm{H}$ bond. Thus $\mathrm{d}^{6} \mathrm{M}(\mathrm{CO})_{5}$ fragments favour $\eta^{2}-\mathrm{H}_{2}$ complexes whereas with pure $\sigma$-donor ligands dihydrides are more likely to be formed. Calculations on mixed donor ligand sets showed that placing a $\mathrm{CO}$ trans to the binding site favoured the $\eta^{2}-\mathrm{H}_{2}$ form due to direct competition for $\pi$-back donation through a common $\mathrm{d} \pi$ orbital. This rationalised the observation that, in the Kubas complex, the dihydrogen ligand lies parallel to the P-W-P axis.

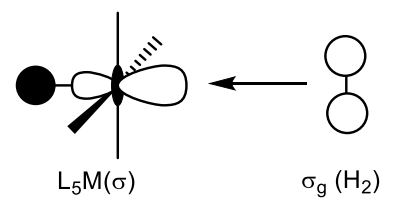

$1 a$

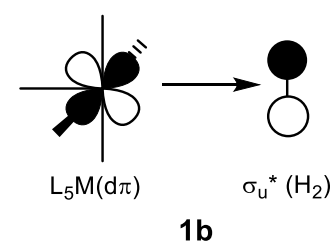

$1 b$

This theme was developed with Ken Caulton in a detailed analysis of the structure of cis,mer$\mathrm{Fe}(\mathrm{H})_{2}\left(\eta^{2}-\mathrm{H}_{2}\right)\left(\mathrm{PEtPh}_{2}\right)_{3}, 2$, in which the $\eta^{2}-\mathrm{H}_{2}$ ligand lies in a staggered orientation with respect to the cis-P-Fe-P plane and the Fe-H axis. ${ }^{4}$ Molecular mechanics (MM2) calculations indicated that this was not a steric effect and the observed orientation was also at odds with the narrow trans-P1-Fe-P3 angle of $149^{\circ}$. This sort of distortion enables d-p hybridisation at the metal and therefore enhances $\pi$-back donation into the $\sigma_{u}{ }^{*}$ of $\mathrm{H}_{2}$, thus usually encouraging the $\mathrm{H}_{2}$ ligand to align with that plane, 3 . Indeed, this accounts for the alignment of the $\eta^{2}-\mathrm{H}_{2}$ ligand in trans$\left[\mathrm{Fe}(\text { dppe })_{2}(\mathrm{H})\left(\mathrm{H}_{2}\right)\right]^{+}$where it eclipses the more acute trans-P-Fe-P angle. Instead EHT calculations revealed the importance of a new type of stabilizing interaction arising from overlap of the filled orbital associated with a hydridic M-H bond and the empty $\sigma_{u}^{*}$ of $\mathrm{H}_{2}$. Thus the observed staggered conformation is a compromise between maximising both this interaction (and hence $\mathrm{H}_{2}$ lying parallel to the $\mathrm{Fe}-\mathrm{H}$ bond) and $\pi$-back donation by aligning with the $\mathrm{P}_{1}-\mathrm{Fe}-\mathrm{P}_{3}$ plane. This novel $\mathrm{H}^{\delta-\cdots} \mathrm{H}-\mathrm{H}$ interaction was proposed simultaneously to weaken the $\mathrm{H}-\mathrm{H}$ bond 
whilst creating a nascent $\mathrm{H} \cdots \mathrm{H}$ interaction that could facilitate the $\mathrm{H}_{2} / \mathrm{H}$ exchange seen in many dihydrogen/hydride complexes. For the specific case of cis,mer-Fe $(\mathrm{H})_{2}\left(\mathrm{H}_{2}\right)\left(\mathrm{PEtPh}_{2}\right)_{3}$ scrambling of $\mathrm{H}_{2}$ is proposed to occur without formation of a classical tetrahydride $\mathrm{Fe}(\mathrm{H})_{4} \mathrm{P}_{3}$. This proposal presages the concept of $\sigma$-bond metathesis reactions at late transition metals and the $\sigma$-CAM mechanism later proposed by Perutz and Sabo-Etienne. ${ }^{5}$

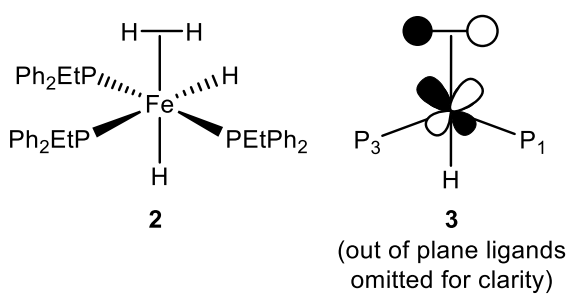

This concept of an incipient $\mathrm{H} \cdots \mathrm{H}$ interaction was extended to contrast the behaviour of cis$\mathrm{L}_{4} \mathrm{TM}(\mathrm{H})_{2}$ and $\mathrm{CpML}(\mathrm{H})_{3}$ transition metal hydrides with that of their isolobal organic analogues $\mathrm{CH}_{4}$ and $\mathrm{CH}_{5}{ }^{+}{ }^{6}$ Fragment analyses pinpointed the key differences between these different classes of compounds to originate in the nodal structure of the $\sigma$-acceptor orbitals of the $\mathrm{L}_{4} \mathrm{M}^{2+}, \mathrm{CpML}^{2+}$ and $\mathrm{CR}_{2}^{2+}$ fragments. With transition metals this is dominated by $\mathrm{d}_{\mathrm{z} 2}$ character (4a) and so disfavours donation from in-phase linear combinations of the hydride group orbitals that sit in the nodal region of the acceptor orbital. As a result more electron density is retained on the hydride ligands and, moreover, this resides in a group orbital that is formally bonding between adjacent hydride centres. In contrast the $\sigma$-acceptor orbital of the $\mathrm{CH}_{2}{ }^{2+}$ fragment is dominated by p-character (4b) that can overlap and hence depopulate the in-phase hydride group orbitals. The spherical nature of the hydride $1 \mathrm{~s}$ orbital also facilitates their interaction and contrasts with the directional $\mathrm{sp}^{3}$-hybrid of alkyl groups. Thus adjacent hydride ligands may readily undergo reductive coupling to their $\eta^{2}-\mathrm{H}_{2}$ form whereas the equivalent process is far less accessible in analogous dialkyls. $\mathrm{H}_{2} \cdots \mathrm{H}$ interactions also determined the orientation of the $\mathrm{H}_{2}$ ligand in $\mathrm{RuH}\left(\mathrm{H}_{2}\right) \mathrm{I}\left(\mathrm{PCy}_{3}\right)_{2}$, the first $16 \mathrm{e} \eta^{2}-\mathrm{H}_{2}$ complex published in 1991 with Bruno Chaudret and Fernando Lahoz. ${ }^{7}$ 


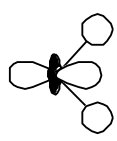

$4 a$

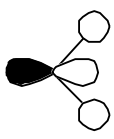

4b

A new theme concerning the stereochemistry of $d^{6} \mathrm{ML}_{5}\left(\eta^{2}-\mathrm{H}_{2}\right)$ complexes and in particular the geometric preferences of the unsaturated $\mathrm{ML}_{5}$ fragment emerged from the study of the reactions of $\operatorname{IrH}(\mathrm{Cl})_{2}\left(\mathrm{PR}_{3}\right)_{2}$ with $\mathrm{H}_{2}{ }^{8} \operatorname{IrH}(\mathrm{Cl})_{2}\left(\mathrm{PR}_{3}\right)_{2}$ itself adopts a square-pyramidal (SP) structure with trans bulky phosphines $\left(\mathrm{P}^{\mathrm{i} \mathrm{Pr}_{3}}\right.$ or $\left.\mathrm{P}^{\mathrm{t}} \mathrm{Bu}_{2} \mathrm{Ph}\right)$ and the hydride occupying the axial site. Experimentally this species reversibly adds $\mathrm{H}_{2}$ trans to the hydride to give $\mathbf{5}_{\text {trans }}$, while over longer periods the cis isomer, $\mathbf{5}_{\text {cis }}$, is formed. $\mathbf{5}_{\text {cis }}$ then loses $\mathrm{HCl}$ to give $\operatorname{Ir}(\mathrm{H})_{2} \mathrm{Cl}\left(\mathrm{PR}_{3}\right)_{2}, \boldsymbol{6}$, for which a neutron diffraction study (with $\mathrm{PR}_{3}=\mathrm{P}^{\mathrm{t}} \mathrm{Bu}_{2} \mathrm{Ph}$ ) shows a distorted trigonal bipyramidal (TBP) structure with a rather short $\mathrm{Ir}-\mathrm{Cl}$ bond of $2.410 \AA$, an acute $\mathrm{H}-\mathrm{Ir}-\mathrm{H}$ angle of $72.7^{\circ}$ and $\mathrm{Cl}-$ Ir- $\mathrm{H}$ angles of $131.1^{\circ}$ and $156.2^{\circ}$.
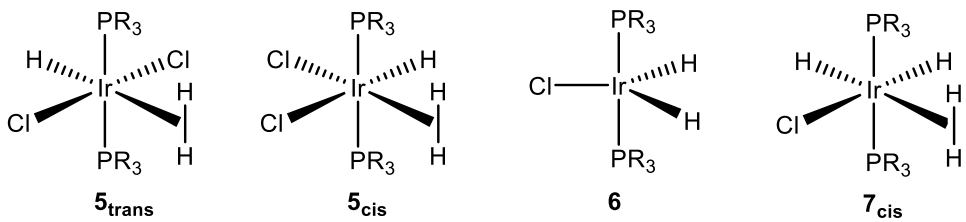

Odile had already presented the MO landscape required to understand the structures of $\mathrm{d}^{6}$ $\mathrm{M}(\mathrm{X}) \mathrm{H}_{2} \mathrm{~L}_{2}$ fragments in an EHT paper with Yves Jean published in her beloved Nouveau Journal de Chimie in $1990 .^{9}$ With the ligands L occupying the axial positions, the geometry is determined by the arrangement of the three $\mathrm{H}$ and $\mathrm{X}$ ligands in the equatorial plane (see Figure 1). For $X=H$ the ideal $D_{3 h}$ TBP geometry is subject to a Jahn-Teller distortion due to partial occupation of the formally degenerate e' pair of orbitals $\left(x y\right.$ and $\left.x^{2}-y^{2}\right)$. Widening one H-M-H 
angle stabilises $x y$ and destabilises $x^{2}-y^{2}$ while narrowing the $\mathrm{H}-\mathrm{Ir}-\mathrm{H}$ angle stabilises $\mathrm{x}^{2}-\mathrm{y}^{2}$ and destabilises $\mathrm{xy}$. When $\mathrm{X}$ is a strong $\sigma$-donor (such as $\mathrm{H}$ ), the former scenario is favoured and gives a SP $\mathrm{T}_{\mathrm{H}}$ geometry; however when $\mathrm{X}$ is a relatively weak $\sigma$-donor and a $\pi$-donor (such as $\mathrm{Cl}$ ) a narrowing of the H-M-H angle is preferred and a $\mathrm{Y}_{\mathrm{X}}$ geometry is seen that can then benefit from $\pi$-donation into the now vacant xy orbital.

Returning to the $\operatorname{IrCl}(\mathrm{H})_{2}\left(\mathrm{PR}_{3}\right)_{2}$ study, $\mathrm{HF}$ calculations on a model $\operatorname{IrCl}(\mathrm{H})_{2}\left(\mathrm{PH}_{3}\right)_{2}$ system confirmed the preference for a $\mathrm{Y}_{\mathrm{Cl}}$ geometry, with the enhanced $\mathrm{Cl} \rightarrow \mathrm{Ir} \pi$-donation also accounting for the short $\mathrm{Ir}-\mathrm{Cl}$ bond length. The calculations suggested a symmetrical $\mathrm{C}_{2 \mathrm{v}}$ structure in contrast to the distorted $\mathrm{Y}_{\mathrm{Cl}}$ shape seen in the experimental structure of $\operatorname{IrCl}(\mathrm{H})_{2}\left(\mathrm{P}^{\mathrm{B}} \mathrm{Bu}_{2} \mathrm{Ph}\right)_{2}$. This discrepancy was suggested to arise from two factors: firstly the calculations indicate that a $\mathrm{T}_{\mathrm{H}}$ structure, although not a stationary point, lies only $3.3 \mathrm{kcal} / \mathrm{mol}$ above the $\mathrm{Y}_{\mathrm{Cl}}$ minimum and so distortion toward that shape is energetically accessible; secondly, the presence of short $\mathrm{Ir}-\mathrm{H} \cdots \mathrm{H}-\mathrm{C}$ contacts with the $\mathrm{P}^{\mathrm{t}} \mathrm{Bu}_{2} \mathrm{Ph}$ ligands in the experimental system that drive the geometry away from the idealised $\mathrm{C}_{2 \mathrm{v}}$ structure.

(a)

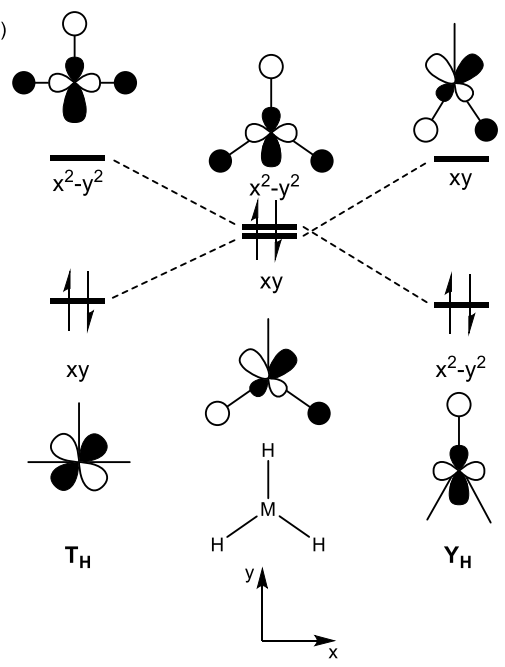

(b)

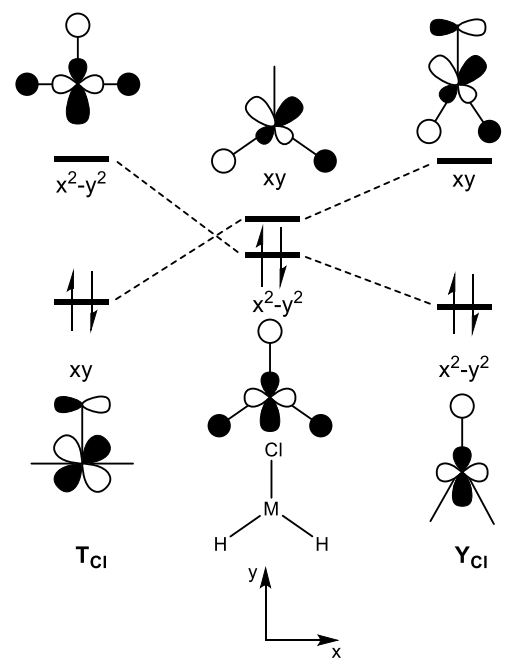


Figure 1. Energy diagram $\left(\mathrm{T} \rightarrow \mathrm{TBP} \rightarrow \mathrm{Y}\right.$ ) for $(\mathrm{a}) \mathrm{IrH}_{3}\left(\mathrm{PH}_{3}\right)_{2}$ and (b) $\operatorname{IrClH}_{2}\left(\mathrm{PH}_{3}\right)_{2}$ with the axial phosphine ligands omitted for clarity. Adapted from Reference 10.

The understanding provided by the EHT treatment of $\mathrm{d}^{6} \mathrm{MXH}_{2} \mathrm{~L}_{2}$ fragments, coupled with the ability of HF (and later, DFT) calculations to optimise structures and provide increasingly more reliable relative energetics allowed a rationale of the structures formed upon addition of $\mathrm{H}_{2}$ to

$\operatorname{IrCl}_{2}(\mathrm{H})\left(\mathrm{PR}_{3}\right)_{2}$ and $\operatorname{IrCl}\left(\mathrm{H}_{2}\left(\mathrm{PR}_{3}\right)_{2}\right.$. For $\operatorname{IrCl}_{2}(\mathrm{H})\left(\mathrm{PR}_{3}\right)_{2}$ the $\mathrm{T}_{\mathrm{H}}$ and $\mathrm{T}_{\mathrm{Cl}}$ fragments within $\mathbf{5}_{\text {trans }}$ and $\mathbf{5}_{\text {cis }}$ are relatively close in energy and so the strength of $\mathrm{M}-\mathrm{H}_{2}$ interaction determines the isomeric preference. This was computed to be significantly stronger for $\mathrm{T}_{\mathrm{Cl}}$ as this places $\mathrm{H}_{2}$ opposite the much weaker trans influence $\mathrm{Cl}$ ligand. This was also consistent with the observation of $\mathbf{5}_{\text {trans }}$ upon initial exposure of $\operatorname{IrCl}_{2}(\mathrm{H})\left(\mathrm{PR}_{3}\right)_{2}$ to $\mathrm{H}_{2}$ at low temperature; this turns out to be a kinetic product the formation of which reflects the easier approach of $\mathrm{H}_{2}$ to the vacant site. Weak $\operatorname{Ir}-\left(\eta^{2}-\right.$ $\mathrm{H}_{2}$ ) binding (trans to hydride) means this process is reversible and so this frees $\mathrm{H}_{2}$ to access the more kinetically difficult approach cis to hydride to form $\mathbf{5}_{\text {cis }}$ as the thermodynamic product. With $\operatorname{IrCl}(\mathrm{H})_{2}\left(\mathrm{PR}_{3}\right)_{2}$ the fact that only cis- $\operatorname{IrCl}(\mathrm{H})_{2}\left(\eta^{2}-\mathrm{H}_{2}\right) \mathrm{CI}\left(\mathrm{PR}_{3}\right)_{2}, \quad 7_{\text {cis }}$, is observed experimentally reflects a strong preference for the $\mathrm{T}_{\mathrm{H}} \mathrm{IrCl}(\mathrm{H})_{2}\left(\mathrm{PR}_{3}\right)_{2}$ fragment; in this case the $\mathrm{T}_{\mathrm{Cl}}$ fragment is $35 \mathrm{kcal} / \mathrm{mol}$ higher in energy and so this effectively rules out $\operatorname{trans}-\operatorname{IrCl}(\mathrm{H})_{2}\left(\eta^{2}-\right.$ $\left.\mathrm{H}_{2}\right) \mathrm{CI}\left(\mathrm{PR}_{3}\right)_{2}$ as a viable structure.

\section{$\pi$-stabilisation of formally unsaturated $d^{6}$ metal complexes.}

Understanding the factors governing the energies of formally unsaturated 16e species was a theme that developed in Odile's research throughout the 1990s, often in collaboration with Ken Caulton. The relevance of such work to catalysis is nicely expressed by the opening lines of a 1992 paper with Michael Pélissier: ${ }^{10}$ "Electron- and ligand-deficient transition-metal complexes are important intermediates in organometallic chemistry. They are usually highly reactive species and cannot be easily observed. However, the understanding of reaction paths can be improved by isolation and characterization of stabilized models of the reactive intermediates." 
This paper built on the 1990 EHT study ${ }^{9}$ by using more quantitative HF and MCSCF (multiconfigurational self-consistent field) calculations. The MCSCF approach indicated that the $\operatorname{Ir}(\mathrm{H})_{3}\left(\mathrm{PH}_{3}\right)_{2}$ model system could be reasonably described with a single, closed shell configuration and the TBP triplet form of this species was also shown to be very high in energy. A series of $\mathrm{IrX}(\mathrm{H})_{2}\left(\mathrm{PH}_{3}\right)_{2}$ species featuring $\pi$-donors $\left(\mathrm{X}=\mathrm{Cl}, \mathrm{NH}_{2}, \mathrm{OR} ; \mathrm{R}=\mathrm{H}, \mathrm{CH}_{3}, \mathrm{CH}_{2} \mathrm{~F}, \mathrm{CF}_{3}\right)$ were all shown to prefer a $\mathrm{Y}_{\mathrm{X}}$ structure with notably shortened $\mathrm{Ir}-\mathrm{X}$ bonds due to the additional $\pi$-stabilisation permitted by this geometry. This also explains the distinct orientational preference seen with a single faced $\pi$-donor such as $\mathrm{NH}_{2}$ and experimentally for the alkoxide ligand in $\operatorname{Ir}(\mathrm{H})_{2}\left(\mathrm{OCH}_{2} \mathrm{CF}_{3}\right)\left(\mathrm{PCy}_{3}\right)_{2}$ in which the $\mathrm{O}-\mathrm{C}$ bond lies parallel to the axial P-Ir-P axis. ${ }^{11}$ This orientation permits $\pi$-donation from a pure p-orbital on the alkoxide ligand, an electronic effect which dominates even in the presence of bulky axial phosphines that might suggest an unfavourable steric interaction.

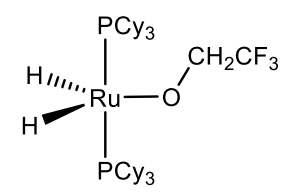

8

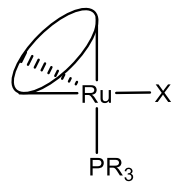

9

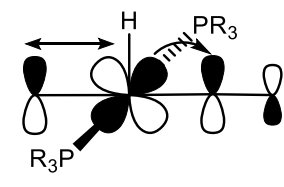

10

The ability of $\pi$-donor ligands, $X$, to stabilise formally unsaturated 16e metal complexes was probed for a series of $16 \mathrm{e} \mathrm{Cp} * \mathrm{Ru}\left(\mathrm{PR}_{3}\right) \mathrm{X}$ complexes $\left(\mathrm{PR}_{3}=\mathrm{P}^{\mathrm{P} P{ }_{2}} \mathrm{Ph}\right.$ or $\left.\mathrm{PCy}_{3}\right){ }^{12}$ An EHT study showed that the planar structure adopted by such species is related to a TBP in which the cyclopentadienyl ligand occupies three facial coordination sites and presents a vacant orbital for $\pi$-donation from $\mathrm{X}$ (see 9). Reaction with $\mathrm{CO}$ formed a series of adducts $\mathrm{Cp} * \mathrm{Ru}(\mathrm{CO})\left(\mathrm{PR}_{3}\right) \mathrm{X}$ for which the observed $v_{\mathrm{CO}}$ stretching frequencies gave a measure of the donating ability of $\mathrm{X}$, with this following the trend $\mathrm{X}=\mathrm{I}<\mathrm{Br}<\mathrm{Cl}<<\mathrm{OCH}_{2} \mathrm{CF}_{3}<\mathrm{OSiPh}_{3}<\mathrm{NHPh}<\mathrm{OSiMe}_{2} \mathrm{Ph}$. The significant elongation of the $\mathrm{Ru}-\mathrm{X}$ bond upon $\mathrm{CO}$ addition indicated the presence of some degree of Ru-X multiple bonding in the 16e electron species. These were therefore termed operationally 
unsaturated with variable $\pi$-donation from $\mathrm{X}$ providing different degrees of stabilization across a series of formally unsaturated $16 \mathrm{e}$ species.

A related study on $\mathrm{Ru}(\mathrm{X})\left(\mathrm{H}(\mathrm{CO})\left(\mathrm{P}^{\mathrm{B}} \mathrm{Bu}_{2} \mathrm{Me}\right)_{2}\right.$ complexes also sought to use $v_{c o}$ stretching frequencies to assess the overall donor strength of the $\pi$-donor ligands $X(X=$ halide, $\mathrm{OR}, \mathrm{NHPh}$, $\left.\mathrm{SPh}, \mathrm{C}_{2} \mathrm{Ph}\right) .{ }^{13}$ These species adopt a $\mathrm{T}_{\mathrm{H}}$ structure with the $\pi$-donor $\mathrm{X}$ trans to $\mathrm{CO}$, an arrangement that allows the $\pi$-acceptor CO ligand to alleviate the $4 \mathrm{e}$ destabilisation associated with the $\mathrm{X}(\pi)$ $\mathrm{Ru}(\mathrm{d} \pi)$ interactions. This so-called 'push-pull' interaction (10) results in shortened $\mathrm{Ru}-\mathrm{X}$ bonds and hence a degree of $\pi$-stabilisation of the metal centre, even though no orbital is formally available on the metal to engage in $\pi$-interaction. The subsequent experimental isolation of $\mathrm{Ru}(\mathrm{H})_{2}(\mathrm{CO})\left(\mathrm{P}^{\mathrm{t}} \mathrm{Bu}_{2} \mathrm{Me}\right)_{2}$ demonstrated that such $16 \mathrm{e}$ species can be accessible even in the absence of $\pi$-donors. ${ }^{14}$ This study highlighted that a major factor in the stability of all these $T_{H} 16 \mathrm{e}$ systems is the presence of the powerful $\sigma$-donating hydride ligand trans to the vacant site; this pushes up the LUMO of the system and so reduces Lewis acidity. The related $\mathrm{Ru}(\mathrm{H})\left(\mathrm{SiR}_{3}\right)(\mathrm{CO})\left(\mathrm{P}^{\mathrm{t} B \mathrm{Bu}_{2} \mathrm{Me}}\right)_{2}$ complexes $\left(\mathrm{SiR}_{3}=\mathrm{SiMe}_{3}\right.$ and $\left.\mathrm{SiPh}_{2} \mathrm{H}\right)$ exhibit $\mathrm{T}_{\mathrm{SiR} 3}$ geometries indicating that these silyl ligands are even more potent $\sigma$-donors than hydride.

A further manifestation of differential ligand donor effects was seen in the structures of neutral $\mathrm{RuX}(\mathrm{CO})(\mathrm{NO})\left(\mathrm{PBu}_{2} \mathrm{Me}\right)_{2}$ species $\left(\mathrm{X}=\mathrm{H}^{-}, \mathrm{F}^{-}, \mathrm{Cl}^{-}, \mathrm{BF}_{4}^{-}\right)$and the related cations $\left[\mathrm{RuL}(\mathrm{CO})(\mathrm{NO})\left(\mathrm{P}^{t} \mathrm{Bu}_{2} \mathrm{Me}\right)_{2}\right]^{+}\left(\mathrm{L}=\mathrm{CO}, \mathrm{CH}_{3} \mathrm{CN}, \mathrm{H}_{2} \mathrm{O}\right) .{ }^{15} \quad$ These systems can exhibit either a SP $\mathrm{Ru}(\mathrm{II})$ structure with a bent $\mathrm{NO}^{-}$ligand (11a) or a TBP $\mathrm{Ru}(0)$ structure featuring linear $\mathrm{NO}^{+}$ (11b). With $\mathrm{X}=\mathrm{F}^{-}, \mathrm{Cl}^{-}$and $\mathrm{BF}_{4}^{-} \mathrm{SP} \mathrm{Ru}(\mathrm{II})$ species are seen with $v_{\mathrm{NO}}$ stretching frequencies observed around $1570 \mathrm{~cm}^{-1}$. For $\mathrm{L}=\mathrm{CO}$ a much higher $v_{\mathrm{NO}}$ of $1738 \mathrm{~cm}^{-1}$ implies a TBP $\mathrm{Ru}(0)$ structure and this structure was also seen crystallographically for $\operatorname{RuH}(\mathrm{CO})(\mathrm{NO})\left(\mathrm{P}^{\mathrm{t}} \mathrm{Bu}_{2} \mathrm{Me}\right)_{2}$ for which $v_{\mathrm{NO}}$ is observed at $1616 \mathrm{~cm}^{-1}$. 

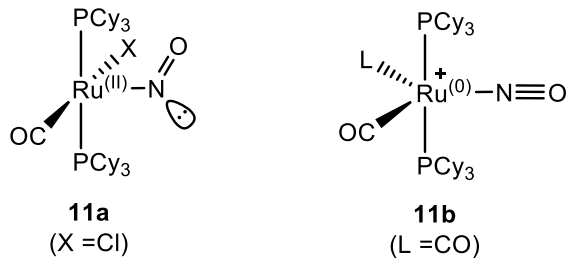

B3LYP calculations captured this trend, with SP Ru(II) structures located for $\mathrm{X}=\mathrm{Cl}^{-}$and $\mathrm{BF}_{4}^{-}$, while with $\mathrm{X}=\mathrm{H}^{-}$or $\mathrm{L}=\mathrm{CO}$ both $\mathrm{SP} \mathrm{Ru}(\mathrm{II})$ and $\mathrm{TBP} \mathrm{Ru}(0)$ structures were found to be local minima with similar energies. In these cases the SP structures had computed Ru-N-O angles of around $120-130^{\circ}$ while in the TBP the Ru-N-O angle was close to linear. An interesting situation arose when $\mathrm{L}=\mathrm{HCN}$, for which both $\mathrm{SP}$ and $\mathrm{TBP}$ structures were located. In the latter the computed Ru-N-O angle was $154^{\circ}$ and a similar geometry was found for 4-coordinate $\left[\mathrm{Ru}(\mathrm{CO})(\mathrm{NO})\left(\mathrm{PR}_{3}\right)_{2}\right]^{+}\left(\mathrm{Ru}-\mathrm{N}-\mathrm{O}\right.$ angle $\left.=147^{\circ}\right)$. Such cases make the assignment of a formal oxidation state problematic and the adoption of non-integer oxidation states was recommended. While the determination of formal oxidation state can often be ambiguous, these systems provided a nice example where such subtle changes are reflected in the geometrical changes of the NO ligand.

\section{Introducing Real Ligands with Steric Effects}

In the mid-1990s, methodological developments and increasing hardware resources were bringing computational chemistry to the level of maturity necessary for quantitative reproduction of homogeneous catalysis systems. A significant step in this gradual process was the ability to compute accurately systems involving realistic ligands, moving finally away from simplified ligand models such as $\mathrm{PH}_{3}$. Odile was again leading the way, and she made a number of contributions in this field.

A first contribution in this area is the rationalization of the structure of the $\mathrm{OsCl}_{2} \mathrm{H}_{2}\left(\mathrm{P}^{i} \mathrm{Pr}_{3}\right)_{2}$ complex. ${ }^{16}$ This $\mathrm{d}^{4} \mathrm{ML}_{6}$ species has a trigonal prism coordination. The expected geometry for this electron count and coordination number is a bicapped tetrahedron, which had been in fact the result of previous calculations with an $\mathrm{OsCl}_{2} \mathrm{H}_{2}\left(\mathrm{PH}_{3}\right)_{2}$ model. ${ }^{17}$ Introduction of the real tris(isopropyl)phosphine in the calculation leads to results in much better agreement with experiment, with a key dihedral angle changing by more than $30^{\circ}$. The reasons for the distortion 
are steric interactions between the chloride ligands and the bulky substituents in the phosphine ligands. The steric nature of the interactions is further confirmed by the fact that these calculations were carried out with a $\mathrm{QM} / \mathrm{MM}$ method, IMOMM,${ }^{18}$ which is a variety of ONIOM, and the phosphine substituents were placed in the MM region. This work required the tuning of van der Waals parameters for the MM description of chloride, ${ }^{19}$ which were also used in the same period for the reproduction of inter-ligand steric effects in another complex..$^{20}$

The collaboration with the group of Caulton on the structural characterization of $\mathrm{d}^{8}$ complexes of ruthenium and iridium with bulky $\mathrm{P}^{t} \mathrm{Bu}_{2} \mathrm{Me}$ and $\mathrm{P}^{t} \mathrm{Bu}_{2} \mathrm{Ph}$ ligands is representative of developments taking place at the time in the computational chemistry of transition metal complexes. A first study ${ }^{21}$ on the structure of the $d^{8} \mathrm{Ru}(\mathrm{CO})_{2}\left(\mathrm{P}^{t} \mathrm{Bu}_{2} \mathrm{Me}\right)_{2}$ focused on the nonplanar structure of this species, and could be carried out safely with MP2 calculations on a $\mathrm{Ru}(\mathrm{CO})_{2}\left(\mathrm{PH}_{3}\right)_{2}$ model. It could be demonstrated with $\mathrm{MO}$ analysis that the non-planarity was associated to the $\pi$-accepting abilities of the CO ligands. A subsequent study ${ }^{22}$ on the $\mathrm{d}^{6}$ $\left[\mathrm{Ru}(\mathrm{Ph})(\mathrm{CO})\left(\mathrm{P}^{t} \mathrm{Bu}_{2} \mathrm{Me}\right)_{2}\right]^{+}$complex demonstrated experimentally the existence of agostic interactions between pendant $\mathrm{C}-\mathrm{H}$ groups in the phosphine ligands and the metal center, with the accompanying B3LYP calculations on the $\left[\mathrm{Ru}(\mathrm{Ph})(\mathrm{CO})\left(\mathrm{PH}_{3}\right)_{2}\right]^{+}$focusing on the eventual agostic interactions between the phenyl ligand and the metal. A later study ${ }^{23}$ on the structure of the $\mathrm{d}^{8}$ complex $\mathrm{Ru}(\mathrm{CO})_{2}\left({ }^{t} \mathrm{Bu}_{2} \mathrm{PC}_{2} \mathrm{H}_{4} \mathrm{P}^{t} \mathrm{Bu}_{2}\right)$, with a chelating ligand, could justify its complex structure with $\mathrm{MO}$ reasonings based on calculations on a $\mathrm{Ru}(\mathrm{CO})_{2}\left(\mathrm{H}_{2} \mathrm{PC}_{2} \mathrm{H}_{4} \mathrm{PH}_{2}\right)$ model system.

The use of simplified phosphines was however insufficient for the qualitative description of the structure of a series of $d^{6} \operatorname{Ir}(\mathrm{III})$ complexes with a generic $\left[\operatorname{Ir}(\mathrm{H})_{2}\left(\mathrm{PR}_{3}\right)_{2}\right]^{+}$formula. A first study ${ }^{24}$ on $\left[\operatorname{Ir}(\mathrm{H})_{2}\left(\mathrm{PBu}_{2} \mathrm{Ph}\right)\right]^{+}$addressed specifically the nature of the agostic interactions between pendant $\mathrm{C}-\mathrm{H}$ groups in the ${ }^{\mathrm{t}} \mathrm{Bu}$ substituents and the iridium center, that had been observed by $\mathrm{X}$ ray diffraction. As a DFT description of the full system was still demanding for the computational resources of the time (1998), a B3LYP study was carried out on the simplified $\left[\operatorname{Ir}(\mathrm{H})_{2}\left(\mathrm{PH}_{2} \mathrm{Et}\right)_{2}\right]^{+}$model containing the bare minimum description that could account for the agostic interaction (See Figure 2). This calculation failed to reproduce any agostic interaction, the $\mathrm{C}-\mathrm{H}$ groups did not approach the strongly electron deficient (14-valence electron) metal center. In contrast, QM/MM calculations (with IMOMM(B3LYP:MM3), with the same QM region of the simplified model reproduced the experimentally observed agostic interaction. The 
agostic interaction was shown thus to be due at least in part to the trapping of the $\mathrm{C}-\mathrm{H}$ bond in the vicinity of the metal center by the steric effects of the other groups of the bulky phosphine. A joint experimental/computational collaboration with the Caulton group further confirmed the role of steric effects in agostic interactions..$^{25}$ The study was extended to $\left[\operatorname{Ir}(\mathrm{H})_{2}(\mathrm{PCy} 2 \mathrm{Ph})\right]^{+}$and $\left[\operatorname{Ir}(\mathrm{H})_{2}\left(\mathrm{P}^{\mathrm{i}} \mathrm{Pr}_{2} \mathrm{Ph}\right)\right]^{+}$, experimental structures were in all cases reproduced by IMOMM(MP2:MM3) calculations on an homologous series of phosphine ligands and the subtle balance between steric and electronic factors could be demonstrated. It is important to notice that the existence of agostic interactions in these compounds is not only a structural curiosity, but an important stabilizing factor for these complexes with low electron count at the metal, which are otherwise very reactive towards electron donors, and are thus directly related to reactivity and ultimately to catalysis.
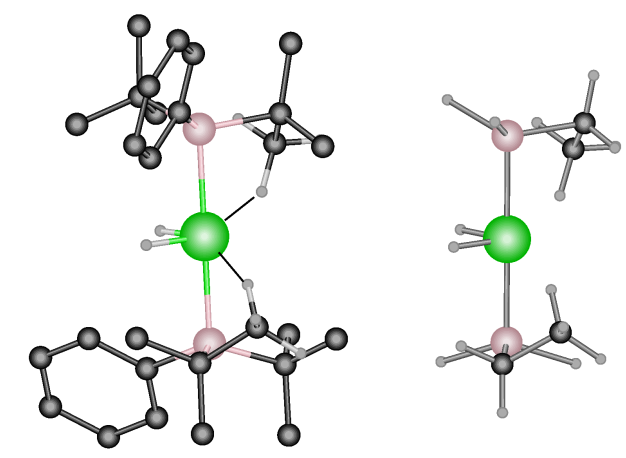

Figure 2. The real $\left[\operatorname{Ir}(\mathrm{H})_{2}\left(\mathrm{PBu}_{2} \mathrm{Ph}\right)_{2}\right]^{+}$complex (left) and the $\left[\operatorname{Ir}(\mathrm{H})_{2}\left(\mathrm{PH}_{2} \mathrm{Et}\right)_{2}\right]^{+}$model used in the most simplified calculations. Non-critical hydrogen terminal atoms omitted for clarity in the representation of the real system.

Another collaboration with the group of Caulton led to the rationalization of the competition between steric and electronic effects in a family of $\mathrm{Ru}(\mathrm{CO})_{2}\left(\mathrm{PR}_{3}\right)_{3}$ complexes. ${ }^{26,27}$ These 5coordinate $\mathrm{d}^{8}$ complexes have the expected trigonal bipyramidal structure, but the particular placement of the ligands depends on the nature of the phosphine substituents. The electronic preference pushes the strong $\pi$-accepting CO ligands to the equatorial sites, as proved by MP2 calculations on the $\mathrm{Ru}(\mathrm{CO})_{2}\left(\mathrm{PH}_{3}\right)_{3}$ model. Steric effects are able to revert this preference to 
different degrees, as shown by experiments and IMOMM(MP2:MM3) calculations on $\mathrm{Ru}(\mathrm{CO})_{2}\left(\mathrm{PEt}_{3}\right)_{3}$ and $\mathrm{Ru}(\mathrm{CO})_{2}\left(\mathrm{P}^{\mathrm{i}} \mathrm{Pr}_{2} \mathrm{Me}_{3}\right)_{3}$.

\section{First Catalytic Cycles}

The possibility of computing real ligands was running parallel with the ability to compute key steps in catalytic cycles, albeit with model systems. Odile's contribution was also substantial in this area. As always, the process was gradual, and one can cite in this regard a significant example of what could be done still at a qualitative level, with Extended Hückel Theory (EHT) calculations. Odile contributed in the early 1990s a study on acetylene trimerization catalyzed by [(triphos)Ir] $]^{+}$complexes. ${ }^{28,29}$ Triphos is a chelating ligand, $\mathrm{MeC}\left(\mathrm{CH}_{2} \mathrm{PPh}_{2}\right)_{3}$, that has the peculiarity of inducing a $f a c$ arrangement with respect to the metal of the three coordinating phosphorus atoms, with P-Ir-P angles around 90 degrees. The EHT study showed that this $f a c$ geometry is key for the observed reactivity, which would be impossible in a mer arrangement, which would be preferred for monodentate phosphines. This arrangement avoids the thermodynamic trap of the trigonal bipyramidal bis(alkyne) complex.

In the late 1990s, the time for quantitative calculation of reaction steps in homogeneous catalysis had finally arrived. This was the period when a study on the competition of aryl-H and aryl-F bonds toward oxidative addition was published. ${ }^{30}$ The thermodynamic and kinetic patterns for oxidative addition of 1,4-difluorobenzene toward two different metal fragments were examined. The study was still carried with model $\mathrm{PH}_{3}$ ligands, but otherwise complete metal coordination spheres were introduced in B3LYP calculations on the reactions of the organic fragment with either $\mathrm{Os}(\mathrm{H})(\mathrm{CO})\left(\mathrm{PH}_{3}\right)_{2}$ or $\mathrm{CpRh}\left(\mathrm{PH}_{3}\right)$. Both types of complexes have been shown to activate $\mathrm{C}$ $\mathrm{H}$ but not C-F bonds. The calculations revealed that, contrary to the general understanding at the time, the main reason for the relative inertness of the C-F bond was not thermodynamic. The C-F bond is certainly very strong, much stronger than $\mathrm{C}-\mathrm{H}$, and calculations confirmed that. But the M-F bond that can be formed after C-F cleavage is also significantly stronger than M-H, thus disproving the hypothesis of the thermodynamic origin. This was demonstrated in the calculations on both osmium and rhodium complexes, with quite different coordination spheres. The transition state calculations on the rhodium complex provided a very different picture for kinetics, with the barriers for the C-F activation higher than those for $\mathrm{C}-\mathrm{H}$ activation by 23.9 $\mathrm{kcal} / \mathrm{mol}$. The difficulty for $\mathrm{C}-\mathrm{F}$ activation $v s \mathrm{C}-\mathrm{H}$ activation is thus not thermodynamic, but 
kinetic. The kinetic inertness of the C-F bond could be moreover justified by the different degree of formation of the $\mathrm{Rh}-\mathrm{C}$ bond in the transition state. This work would constitute the basis for a very fruitful collaboration with Robin Perutz on C-H activation of fluoroarenes. ${ }^{31,32}$

The step from studying quantitatively an important reaction step to computing a full free energy profile was relatively simple, and was crossed by Odile's group in 1998 with the characterization of the four-electron reduction of diazo compounds at a single tungsten metal center in collaboration with Rothwell. Complexes like $\left[\mathrm{W}\left(\mathrm{OC}_{6} \mathrm{HPh}_{3}-\eta^{6}-\mathrm{C}_{6} \mathrm{H}_{5}\right)(\mathrm{OAr})\left(\mathrm{PMe}{ }_{2} \mathrm{Ph}\right)\right](\mathrm{OAr}=$ 2,3,5,6-tetraphenyloxide) had been shown to react with dioxygen and a variety of $\mathrm{RN}=\mathrm{NR}$ ' diazo molecules to produce the corresponding bis(oxo) and bis(imido) derivatives. The formally $\mathrm{d}^{4}$ W(II) metal center is stabilized by an $\eta^{6}$ interaction with the $o$-phenyl ring in one of the aryloxide ligands (see Figure 3). The molecular orbitals potentially involved in the interaction had been analyzed in a preliminary paper with EHT calculations. ${ }^{33}$ The potential energy profile for this multistep process was analyzed with B3LYP calculations on a model system. ${ }^{34}$ The key results are summarized in Figure 3. The simplification of the real system was substantial. The metal-coordinating phenyl ring attached to the alkoxy ligand was replaced by an unsubstituted benzene, and the substituents on the alkoxy, phosphine and diazo groups were replaced by hydrogens. The use of this model allowed the calculation of the complex potential energy surface. 


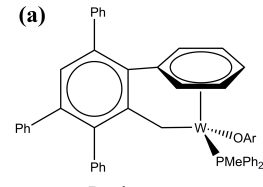

Real system

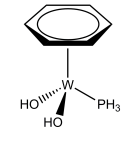

Model system

(b)
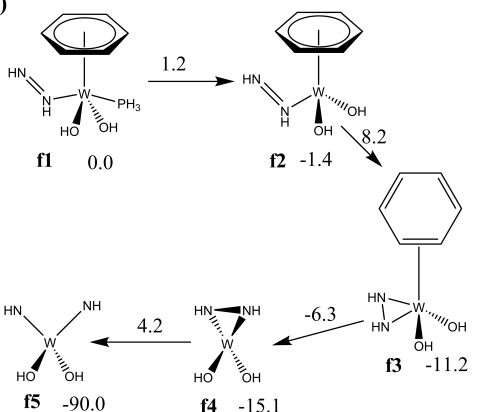

Figure 3. Key structures in the computational study of the four-electron reduction of a diazo compound on a tungsten center. (a) Real system vs model system. (b) Key intermediates with indication of potential energies in $\mathrm{kcal} / \mathrm{mol}$. Energies of the key transition states are also indicated.

The reaction starts with $\eta^{1}$ coordination of the diazo compound to the tungsten center in intermediate f1. This complex evolves rapidly with loss of the phosphine ligand to intermediate f2. Conversion between intermediates $\mathbf{f} 2$ and $\mathbf{f 3}$ has a significant rearrangement in two ligands. On one hand the formally neutral $\eta^{1}$ diazo ligand changes coordination to a formally dianionic $\eta^{2}$. This involves the first two-electron oxidation in tungsten. Also in this step, the phenyl ring changes coordination from $\eta^{6}$ to $\eta^{2}$, likely to make space in the coordination sphere. A further move of the nitrogenated ligand in the tungsten environment leads to loss of the benzene ligand in intermediate f4. Finally intermediate $\mathbf{f 4}$ undergoes the second two-electron oxidation, with cleavage of the $\mathrm{N}-\mathrm{N}$ bond and formation of the diimido product $\mathbf{f 5}$. The conversion from $\mathbf{f 4}$ to $\mathbf{f 5}$ has the highest barrier in all the process, $19.3 \mathrm{kcal} / \mathrm{mol}$, which is still affordable in the experimental conditions. 
This work on four-electron oxidation is representative of the calculations that could be carried out at the time of its publication, 1998. The simplification of the experimental system is very substantial, and the calculations do not involve free energies, but only potential energies. Yet, the study seems to capture the main features of the reaction at hand. As mentioned in the original publication, "The unusual ability of the $\left[\mathrm{W}\left(\mathrm{OC}_{6} \mathrm{HPh}_{3}-\eta^{6}-\mathrm{C}_{6} \mathrm{H}_{5}\right)(\mathrm{OAr})\left(\mathrm{PMe}_{2} \mathrm{Ph}\right)\right]$ complex to lose gradually, and at a relatively low energy cost, several ligands because of the compensating influence of the remaining ligands, which are potent electron donors, is at the heart of this reaction." If the calculations had to be reproduced at present, the methods and the models would be much more sophisticated, but these conclusions would likely hold. This is a good example of how the pioneering work in computational homogeneous catalysis required an extra effort of interpretation to take advantage of the limited resources.

Of course, none of the calculations described in this section involves a full catalytic cycle. Not even in the last case, because the tungsten reactant is not regenerated after the reaction. But the calculations were already able to reproduce a complicated multistep process, and this was an important proof of concept towards the study of full catalytic cycles.

\section{Reactivity of Organolanthanide Complexes}

In the late-1990s, Odile had the opportunity to develop a computational approach that enabled the exploration of the reactivity organolanthanide complexes by using large, $4 \mathrm{f}$ in-core, electron core potentials (ECPs). ${ }^{35}$ This methodology afforded a straightforward access to the computational investigation of the structure and reactivity of organolanthanide complexes. Before that, calculations of the electronic structure of organometallic complexes comprising $4 \mathrm{f}$ elements were significantly hampered by the explicit treatment of the open $4 \mathrm{f}$-shell, and were thus essentially limited to $\mathrm{La}(\mathrm{III})\left(4 \mathrm{f}^{0}\right)$ or $\mathrm{Lu}(\mathrm{III})\left(4 \mathrm{f}^{14}\right)$ complexes or required high level ab initio calculations on small model systems. Though the use of lanthanide large core ECPs does not 
allow to account directly for reactions that are initiated by single electron transfer (SET), it enables to investigate, aside structure and bonding pictures, concerted reaction mechanisms of any lanthanide complex, as long as the metal centre does not change oxidation state. That was opening a field large and challenging enough as single bond activations by $\sigma$-bond metathesis (formally $[2 \sigma+2 \sigma]$ ) and double bond insertions (formally $[2 \sigma+2 \pi]$ ) are the main transformations in the world of organolanthanide chemistry and polymerization catalysis. ${ }^{36}$ This was the starting point of a 15-year research program that has been supported, at its early stage, by an industrial partner (Michelin) and sustained, all along, by key academic collaborations with Andersen and Tilley (U.C. Berkeley) and Lappert (U. Sussex).

The first contribution was the depiction of the $\sigma$-bond metathesis between $\mathrm{H}_{2}$ and $\mathrm{Cp}_{2} \mathrm{LnH}$ and the study of the influence of the lanthanide centre on the energy profile. ${ }^{37}$ Regarding the influence of the lanthanide centre over the energy barriers, though differences are small along the series, the lowest energy barriers were computed for $\mathrm{Nd}, \mathrm{Pm}$ and $\mathrm{Sm}$. The analysis of the geometry and of the electronic structure confirmed the prototypical kite-shape 4 electron / 4 centre transition state that is characteristic of such concerned reactions. It also highlighted the charge alternation shown in Figure 4-a. Thereof the three non-metallic centres $X^{\alpha}-X^{\beta}-X^{\alpha}(\alpha$ and $\beta$ are relative position to $\mathrm{Ln}$ ) involved in the $\sigma$-bond metathesis define a negatively charged hypervalent transient fragment, whereas the $\mathrm{Ln}-\mathrm{X}^{\alpha / \alpha^{\prime}}-\mathrm{X}^{\beta}$ fragment defined a positively charged hypervalent transient fragment. These early results were a set of invitations to further explore heteroatomic single-bond activation selectivities depending on the ability of the atoms involved in the metathesis to stabilize either positively or negatively charged hypervalent states. 


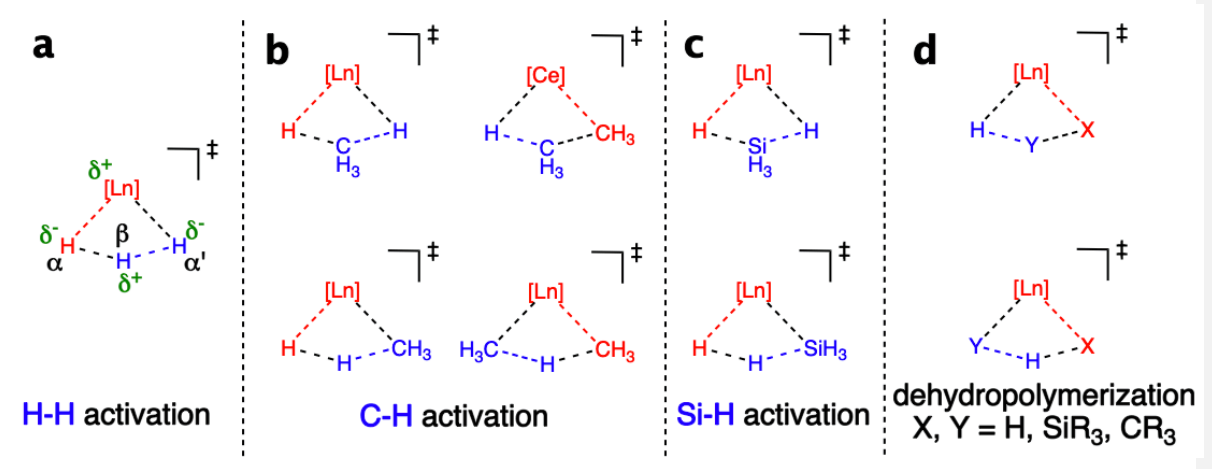

Figure 4. Key transition states in the computational study of $\sigma$-bond metathesis between $\mathrm{Cp}_{2} \mathrm{LnH}$ and $\mathrm{H}_{2}(\mathbf{a}) ; \mathrm{Cp}_{2} \operatorname{LnX}\left(\mathrm{X}=\mathrm{H}, \mathrm{CH}_{3}\right)$ and $\mathrm{CH}_{4}(\mathbf{b}) ; \mathrm{Cp}_{2} \mathrm{LnH}$ and $\mathrm{SiH}_{4}(\mathbf{c}) ; \mathrm{Cp}_{2} \operatorname{LnX}\left(\mathrm{X}=\mathrm{H}, \mathrm{CH}_{3}, \mathrm{Ph}\right.$, $\mathrm{SiH}_{3}$ ) and $\mathrm{CH}_{3}-\mathrm{SiH}_{3}$ or $\mathrm{Ph}-\mathrm{SiH}_{3}(\mathbf{d})$.

Attention was first raised to $\mathrm{C}-\mathrm{H}$ activation of methane mediated by $\mathrm{Cp}_{2} \mathrm{LnH}$ and $\mathrm{Cp}_{2} \mathrm{LnCH}_{3}$ (Figure 4-b). ${ }^{38}$ This study confirmed the experimental reactivity trends that are (i) any reaction in which a carbon atom occupies the $\beta$ position relative to the metal centre is kinetically prohibited; (ii) $\mathrm{H}$ to $\mathrm{CH}_{3}$ exchange is endergonic. In terms of reactivity, this means that $\mathrm{C}-\mathrm{C}$ coupling or activation is illusive and that $\mathrm{H}$ for $\mathrm{D}$ exchange at alkanes cannot proceed via a single chemical event. In terms of concepts, these results reinforced the interpretation based on the (in)stability of a negative hypervalent transient state such as $\left[\mathrm{H}-\mathrm{CH}_{3}-\mathrm{X}\right]^{-}, \mathrm{X}=\mathrm{H}$ or $\mathrm{CH}_{3}$.

In order to pursue this idea, the case of $\mathrm{SiH}_{4}$ as a substrate has been considered. Indeed, silicon is well known to stabilize negative hypervalent structures (Figure 4-c). ${ }^{39}$ In this case, the transition state in which the silicon atom occupies the $\beta$ position relative to the metal is very low in energy and is lower in energy than the transition state in which the silicon atom occupies the $\alpha$ 
position relative to the metal centre though this latter configuration remains low enough in energy to open a competitive chemical route. In terms of reactivity, this was in line with the chemical reactivity trends that account for the dehydropolymerization of silanes. However, as dehydropolymerization of silanes involves organosilanes, both the chemo- and the regioselectivities associated with the activation of $\mathrm{H}-\mathrm{H}, \mathrm{Si}-\mathrm{H}, \mathrm{C}-\mathrm{H}, \mathrm{Si}-\mathrm{C}(\mathrm{Me}$ or $\mathrm{Ph})$ and $\mathrm{Si}-\mathrm{Si}$ have been systematically investigated and compared on the same basis (Figure 4-d) in order to offer a rational and complete picture of the reaction routes and associated selectivities at place during the dehydropolymerization of organosilanes..$^{40,41}$

In the perspective of pushing the limit of the rationale that account for selectivity of $\sigma$-bond metathesis on the basis of the relative stability of the transient hypervalent species, the C-F activation of $\mathrm{CF}_{4}$ by $\mathrm{Cp}_{2} \mathrm{LnH}$ has been considered. ${ }^{42}$ The reactivity concept turned out to be verified, as well, in this case. The transition state in which the carbon atom occupies the $\beta$ position $\left(\left[\mathrm{H}_{-}-\mathrm{CF}_{3}-\mathrm{F}\right]^{-}\right.$hypervalent negative fragment) relative to the metal centre was computed lower in energy than the transition state in which the carbon atom occupies the $\alpha$ position relative to the metal. Unfortunately, both energy barriers were high enough in energy to match any accessible chemical reactivity. But, much more interestingly, following of the intrinsic reaction coordinate along the product from the transition state TS-C $\boldsymbol{\beta} \mathbf{F}$ (Figure 5) revealed a Simmons-Smith reaction type in which the carbenoid $\mathrm{CF}_{2}$ is released and subsequently quenched by HF. This reactivity raised interest. Thereof, the reactivity trends of the activation of the three hydrofluroromethanes $\mathrm{CH}_{3} \mathrm{~F}, \mathrm{CH}_{2} \mathrm{~F}_{2}, \mathrm{CHF}_{3}$ were explored. Experimentally, this reactivity was also of interest to R.A. Andersen. Both experimental and computational investigation were conducted in concert and extended to the defluorination of hydrofluoroarenes. ${ }^{43,44}$ For both types of substrate, it was shown that the reactivity was governed by the transient formation of 
fluorocarbenoid or fluorobenzyne. This reaction scheme by which unsaturated species are generated in situ found additional resonance in the dehypolymerization of stannane. ${ }^{45,46}$

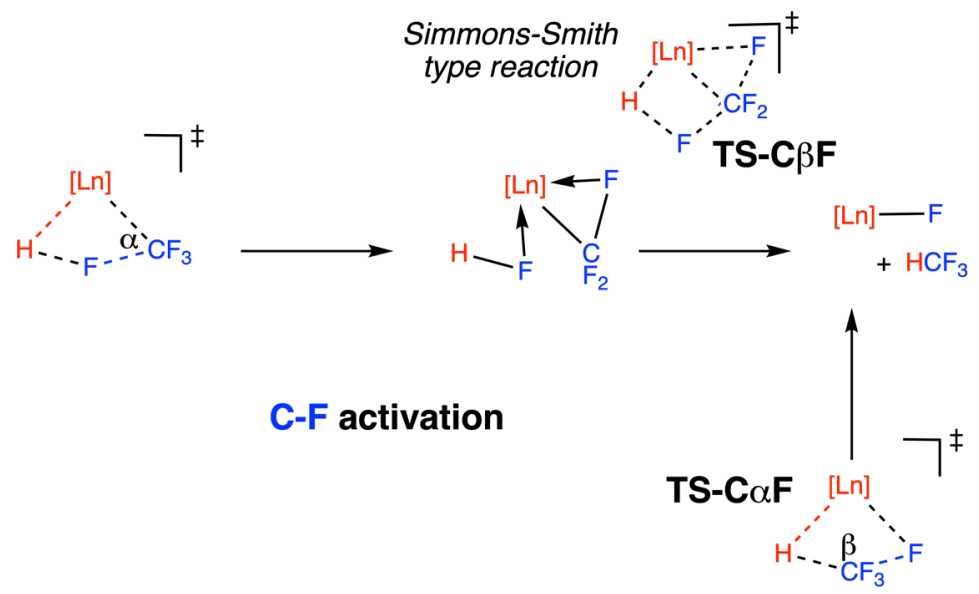

Figure 5. Key transition states in the computational study of $\sigma$-bond metathesis between $\mathrm{Cp}_{2} \mathrm{LnH}$ and $\mathrm{CF}_{4}$.

Finally, the mechanistic study that accounts for the reduction of pyridine by cerocene hydride illustrates the time given to reach almost full coherence between experimental (RA Andersen) and computational contributions. ${ }^{47}$ Preliminary calculations were performed in 2000, then several years of refinements of both experimental data and modelling lead us to detailed picture of the catalytic cycle in which some reduction steps are autocatalytic in cerium hydride, i.e. they require two cerocenes to proceed. Interestingly enough, the protagonists of this story realized that, ironically, the heavily encumbered cerium hydride $\left[1,2,4-\left(\mathrm{Me}_{3} \mathrm{C}\right)_{3} \mathrm{C}_{5} \mathrm{H}_{2}\right]_{2} \mathrm{CeH}$ initially a supprimé: e stories a supprimé: weirdly designed, among other properties, to avoid dimerization turned out to act synergistically, within $\underline{a}$ Ce-dimer, at a key step of the reaction as illustrated in Figure 6. 


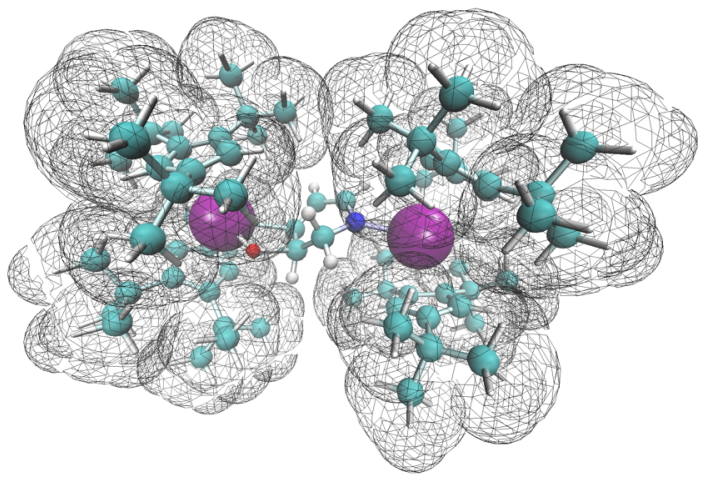

Figure 6. Structure of the transition state for [Ce]'H addition (left) to the meta centre of $(2 \mathrm{H}$ hydropyridyl)[Ce]' (right) on the path to generate piperidine from pyridine under $\mathrm{H}_{2}$ pressure in the presence of $\left[1,2,4-\left(\mathrm{Me}_{3} \mathrm{C}\right)_{3} \mathrm{C}_{5} \mathrm{H}_{2}\right]_{2} \mathrm{CeH}$.

\section{Olefin metathesis catalysis}

In the mid 2000s, the development of computational studies of reaction mechanisms by Odile attracted the interest of various experimentalists eager to gain insight in their catalytic systems. A collaboration with Jean-Marie Basset and Christophe Copéret initiated a line of research on $\mathrm{d}^{0}$ olefin metathesis catalysts with an impact beyond expectation. Experimentally, the fragment $\mathrm{Re}\left(\mathrm{CC}^{t} \mathrm{Bu}\right)\left(\mathrm{CH}^{\mathrm{t} B u}\right)\left(\mathrm{CH}^{t} \mathrm{Bu}\right)$, once grafted on a silica surface, exhibits a high activity for olefin and alkyne metathesis, ${ }^{48}$ contrary to what is observed for corresponding molecular species $\mathrm{Re}\left(\mathrm{CC}{ }^{t} \mathrm{Bu}\right)\left(\mathrm{CH}^{\mathrm{t}} \mathrm{Bu}\right)(\mathrm{OR})\left(\mathrm{R}=\mathrm{CMe}\left(\mathrm{CF}_{3}\right)_{2}\right) .^{49}$ The general understanding on $\mathrm{d}^{0}$-metal based olefin metathesis catalysts at that time was that the presence of electro-attracting fluoro-substituted alkoxy groups increased the electropositive character of the metal center, and hence its reactivity with olefins.

DFT(B3PW91) and QM/MM(B3PW91:UFF) calculations were carried out to rationalize the structural and dynamical properties of quasi-tetrahedral alkylidyne-alkylidene rhenium complexes $\operatorname{Re}(\mathrm{CR})(\mathrm{CHR})(\mathrm{X})(\mathrm{Y})(\mathrm{R}=$ alkyl, $\mathrm{X}=\mathrm{Y}=$ alkyl; $\mathrm{X}=$ alkyl, $\mathrm{Y}=$ siloxy; $\mathrm{X}=\mathrm{Y}=$ 
alkoxy). ${ }^{50}$ An angular distortion at the metal center allows the formation of three metal-carbon $\pi$ bonds and an $\alpha$-agostic interaction with the bond anti to the alkylidyne ligand, i.e. the $\mathrm{C}-\mathrm{H}$ and the $\mathrm{C}-\mathrm{C}$ bond in the syn and anti isomers, respectively.

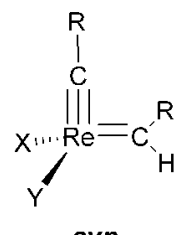

syn

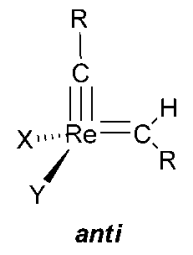

ant $i$

The interconversion between the two isomers is computed to be high in energy and is rationalized by an MO study in terms of competition of $\pi$-donation into the same empty metal orbital. The analysis of the electronic structure indicates that the strength of the C-H agostic interaction originates from the perturbation of the ligand field away from the tetrahedral geometry preferentially to the magnitude of the positive charge on Re.

A further study of the reaction mechanism for olefin metathesis highlights the crucial role played by the nature of the ligands $\mathrm{X}$ and $\mathrm{Y}$ to induce increased activity. ${ }^{51}$ The general mechanism proposed introduces a slight, yet essential, modification of the well-known Chauvin mechanisms (Scheme 1). The actual C-C coupling step leading to the metallacyclobutane intermediate, is preceded by a deformation step of the catalyst enabling olefin coordination. This step does not create any significant interaction between the $\mathrm{C}=\mathrm{C}$ and $\mathrm{Re}=\mathrm{C} \pi$-bonds, but prepares the catalysts for the $\mathrm{C}-\mathrm{C}$ coupling. In order to accommodate the olefin coordination, the pseudo-tetrahedral geometry has to distort to open a face. The energy required is minimized where the ligand $\mathrm{X}$, trans to the olefin, is a good $\sigma$-donor and the ligand $\mathrm{Y}$, trans to the alkylidene is a poor $\sigma$-donor.

\section{Scheme 1}

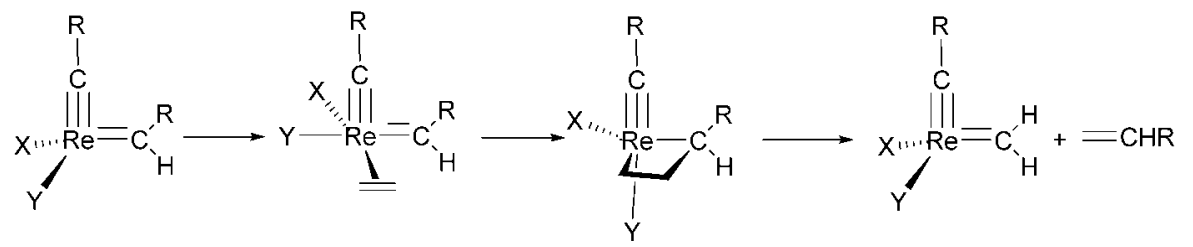


The best catalyst will have the more shallow potential energy surface, and will thus be obtained for the unsymmetrical set of ligands with $\mathrm{X}=$ a good $\sigma$-donor (alkyl) and $\mathrm{Y}=$ a poor $\sigma$-donor (O-based ligand). This rationalizes the high efficiency of the well-defined $\mathrm{Re}$ alkylidene supported on silica, compared to its homogeneous equivalent $\operatorname{Re}(\mathrm{CCR})(\mathrm{CHR})(\mathrm{OR})_{2}$. This study was then extended to $\mathrm{M}(=\mathrm{NR})\left(\mathrm{CHCH}_{3}\right)(\mathrm{X})(\mathrm{Y})$ for $\mathrm{M}=$ Mo or $\mathrm{W}, \mathrm{R}=$ methyl or phenyl, $\mathrm{X}=$ $\mathrm{CH}_{2} \mathrm{CH}_{3}, \mathrm{OCH}_{3}$ or $\mathrm{OSiH}_{3}$, and $\mathrm{Y}=\mathrm{CH}_{2} \mathrm{CH}_{3}, \mathrm{OCH}_{3}$ or $\mathrm{OSiH}_{3}$, which are representative of experimental olefin metathesis catalysts. ${ }^{52}$ The efficiency has been evaluated by calculating the TOF based on the steady-state approximation and unsymmetrical catalysts $(\mathrm{X} \neq \mathrm{Y})$ are systematically more efficient for all systems (Mo, W, and Re).

Quite remarkably, this computational study of the olefin metathesis catalytic cycle provided a new paradigm in catalyst design that resulted in new discoveries, as pointed out by Schrock and Hoveyda : "In the second section, we illustrate how guided by mechanistic principles and inspired by recent theoretical investigations, we have been able to design, synthesize, and develop and exceptionally effective new class of stereogenic-at-Mo olefin metathesis catalysts that readily promote a highly enantioselective synthesis of the target alkaloid." 53

One of the strengths of computational chemistry is the ability to study many different reaction pathways, in particular by-product formation and deactivation pathways in catalysis. This is of the outmost importance in catalyst design as, quite often, very active systems suffer from equally active deactivation pathways or non-selective product formation. Odile, in collaboration with Christophe Copéret, studied the deactivation processes originating from the metallcyclobutane intermediate in olefin metathesis. ${ }^{54}$ The metallacyclobutane intermediate involved in the productive pathway has a trigonal bipyramid geometry with the poor $\sigma$-donor ligand $\mathrm{Y}$ in the axial position, trans to the alkylidyne ( $\mathrm{Re}$ ) or the imido group (Mo, W). This intermediate can isomerize to a more stable square-pyramidal intermediate with the triply bonded ligand (alkylidene, Re; imido, Mo and W) occupying the axial position. From this intermediate, several transformations were considered computationally (Scheme 2). Calculations show that by-product formation and deactivation start by a $\beta$-H transfer trans to the weak $\sigma$-donor ligand (siloxy). This key step has an energy barrier slightly higher than that calculated for olefin metathesis. A further study on the influence of the nature of the strong $\sigma$-donor $\mathrm{X}$ on the competition between productive olefin metathesis and by-product formation or deactivation pathway indicate the crucial role played by the pyrrolyl ligand. ${ }^{5}$ Overall, the greatest benefit of substituting the 
ancillary alkyl $\mathrm{X}$ by a pyrrolyl ligand is in fact not to improve the efficiency of the catalytic cycle of alkene metathesis, but to shut down deactivation and by-product formation. More recently, Odile has studied the relationship between the ${ }^{13} \mathrm{C}$ chemical shift of the alkylidene carbon and the metal coordination geometry and shown how the ${ }^{13} \mathrm{C}$ chemical shift can be a powerful predictor of reactivity. ${ }^{56}$

Scheme 2

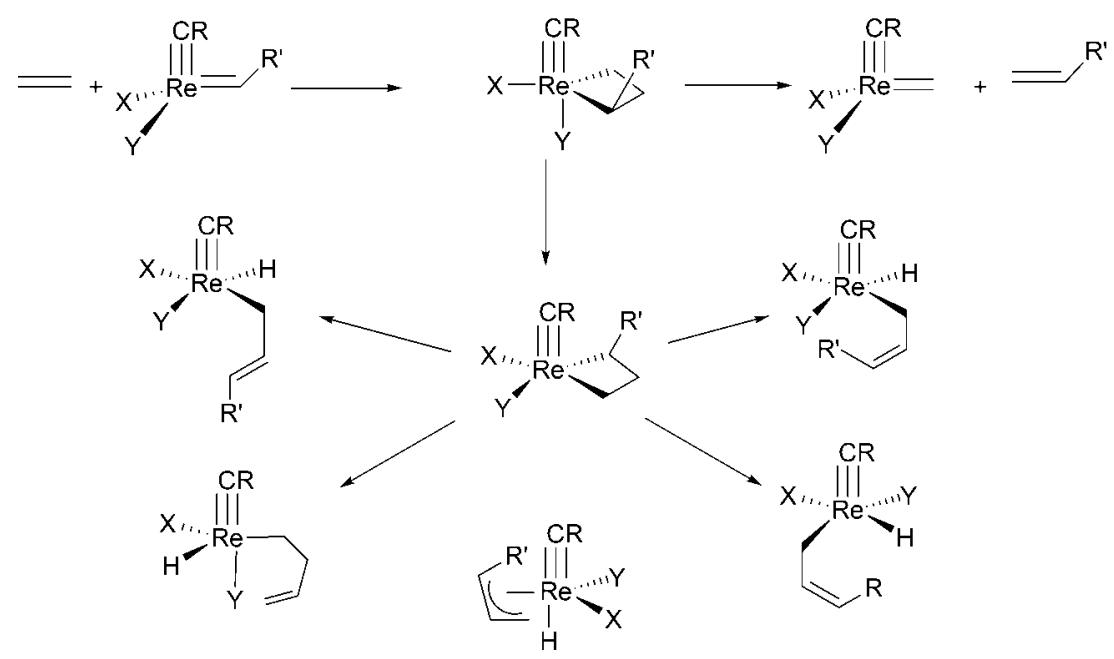




\section{Catalytic C-H Oxidations with Mn Complexes.}

In the late 2000s, the collaboration of Odile with the Crabtree group expanded to the field of metal-catalyzed oxidation reactions. DFT calculations were used to shed light on the mechanism of these reactions, which involve intermediates in high oxidation states. These unstable species were difficult to characterize experimentally and theory was thus used to understand their structure and reactivity. The first work focused on manganese-porphyrins as case study. ${ }^{57}$ These complexes were active in $\mathrm{C}-\mathrm{H}$ oxidation and were regarded as molecular mimics of the metalloenzymes containing the heme group.$^{58,59}$ The computations on the oxidation of toluene to benzyl alcohol by $\mathrm{Mn}(\mathrm{O})(\mathrm{tHp})(\mathrm{Cl})(\mathrm{tHp}=$ porphine $)$ showed that the reaction follows a "classical" rebound mechanism (Figure 7). In the first step, a $\mathrm{Mn}^{\mathrm{v}}$-oxo species initiated the reaction by $\mathrm{H}$-atom abstraction yielding a $\mathrm{Mn}^{\mathrm{IV}}$-hydroxo intermediate and the benzyl radical. This reaction was nearly thermoneutral $\left(\Delta \mathrm{G}=-1.6 \mathrm{kcal} \mathrm{mol}^{-1}\right)$ and involved a low energy barrier of $5.3 \mathrm{kcal} \mathrm{mol}^{-1}$. In the following step, the rebound of the $\mathrm{OH}$ ligand to the radical was almost barrier-less $\left(\Delta \mathrm{G}^{\star}=2.5 \mathrm{kcal} \mathrm{mol}^{-1}\right)$ and strongly exergonic $\left(\Delta \mathrm{G}=-15.6 \mathrm{kcal} \mathrm{mol}^{-1}\right)$, yielding the benzyl alcohol product.

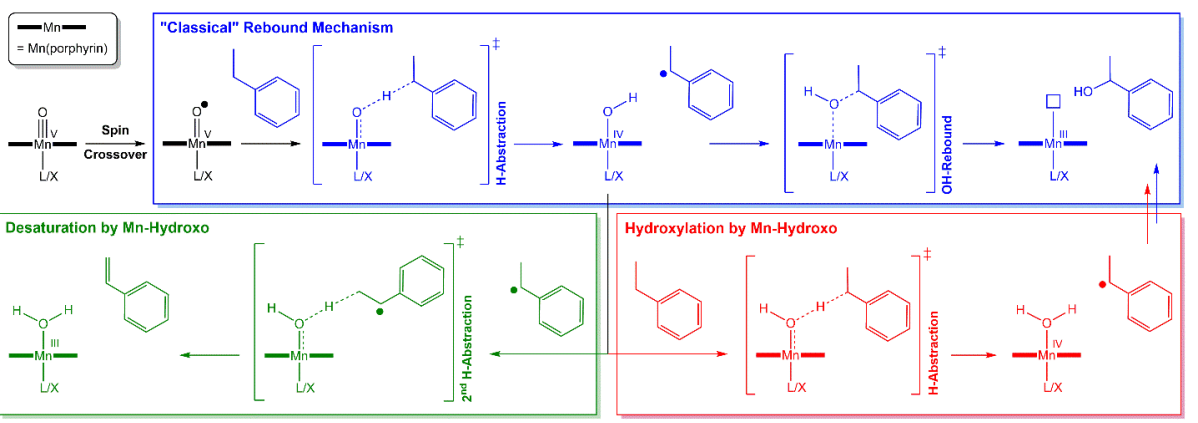


Figure 7. The classical rebound mechanism for $\mathrm{C}-\mathrm{H}$ oxidation by $\mathrm{Mn}(\mathrm{V})$-porphyrin complexes (in blue) and its possible ramifications, including $\mathrm{H}$-abstraction by Mn-hydroxo species yielding either hydroxylated (in red) or dehydrogenated (in green) products.

A key feature of the rebound pathway was the requirement for spin-crossover from the singlet ground state of the $\mathrm{Mn}^{\mathrm{v}}$-oxo complex to the triplet state. The calculations suggested that this activation process should be facile, owing to the small energy difference found between the two spin states (i.e. $3.4 \mathrm{kcal} \mathrm{mol}^{-1}$ ). The triplet state was generated by a $\pi \rightarrow \pi^{*}$ electron excitation to an anti-bonding orbital based on an $\mathrm{O}(p)-\mathrm{Mn}(d)$ out-of-phase combination (Figure 8). The electron population of this $\pi^{*}$ orbital destabilized the $\mathrm{Mn}=\mathrm{O}$ bond, which, in the triplet state, was significantly elongated (1.66 $\AA$ ) relative to the singlet state (1.57 $\AA$ ). Further, the contribution of oxygen to the $\pi^{*}$ orbital gave radical oxyl character to the terminal oxo ligand. The elongated bond and oxyl character features of the $\mathrm{MnO}$ moiety in the triplet state accounted for the low barriers of the rebound pathway. Further, the lack of $\mathrm{C}-\mathrm{H}$ oxidation reactivity in the singlet state, consistent with both theory and experimental evidence, framed these Mn-porphyrin within the two-state-reactivity scenario proposed by Shaik for metal-oxo systems. ${ }^{60}$
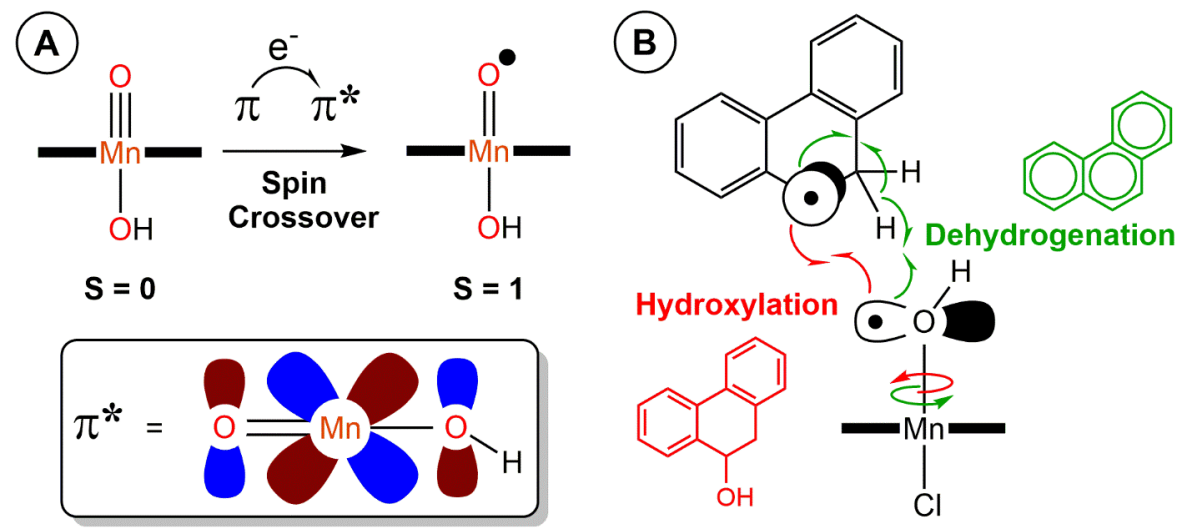

Figure 8. Singlet-to-triplet spin-crossover, including the nature of the $\pi^{*}$-acceptor orbital involved (A) and conformational hydroxylation/dehydrogenation switch in the oxidation of dihydrophenanthrene (B). 
One of the debated features in the oxidation chemistry of manganese porphyrins was the presence of an apical ligand trans to the oxo $(\mathrm{X})$ and its influence on $\mathrm{C}-\mathrm{H}$ oxidation. When $\mathrm{X}$ had acid/base properties, its protonation state had been invoked to account for $\mathrm{pH}$ effects observed experimentally. ${ }^{61}$ Odile tackled this question by exploring reactivity along the $\mathrm{Mn}^{\mathrm{v}}(\mathrm{O})(\mathrm{tHp})(\mathrm{X})^{+}\left(\mathrm{X}=\mathrm{OH}_{2}, \mathrm{OH}^{-}, \mathrm{O}^{2-}\right)$ series..$^{62} \mathrm{In}$ all three cases, the reaction required spincrossover from the singlet ground state to a triplet state with oxyl character, which followed a rebound pathway with the highest barrier associated with the H-abstraction step. The nature of the $\mathrm{X}$ ligand had a dramatic influence on this barrier, which, contrary to the trend expected from trans-influence, changed from a minimum of $-0.6 \mathrm{kcal} \mathrm{mol}^{-1}$ with $\mathrm{X}=\mathrm{OH}_{2}$ to a maximum of $28.9 \mathrm{kcal} \mathrm{mol}^{-1}$ with $\mathrm{X}=\mathrm{O}^{2-}$, through an intermediate value of $11.9 \mathrm{kcal} \mathrm{mol}^{-1}$ with $\mathrm{X}=\mathrm{OH}^{-}$. The $\mathrm{H}$-abstraction barrier had two different energy contributions: 1) the concomitant cleavage and formation of the $\mathrm{C}-\mathrm{H}$ and $\mathrm{O}-\mathrm{H}$ bonds, and 2) the singlet-to-triplet spin crossover. The second factor was clearly the major component of the barrier; e.g., with $\mathrm{X}=\mathrm{O}^{2-}\left(\Delta \mathrm{G}^{*}=28.9 \mathrm{kcal} \mathrm{mol}^{-1}\right)$, the excitation to the triplet state was endergonic by $27.3 \mathrm{kcal} \mathrm{mol}^{-1}$. Owing to this large barrier, and in agreement with experiments, this species was not active in $\mathrm{C}-\mathrm{H}$ oxidation. The influence of the apical ligand was attributed to its contribution to the $\pi^{*}$ orbital hosting one of the unpaired electrons in the triplet state. E.g., in the case of $\mathrm{X}=\mathrm{OH}^{-}$, the metal $d$ orbital was combined out-of-phase not only with a $p$ orbital of the oxo ligand, but also with another $p$ orbital located on the hydroxo ligand (Figure 8). In this context, the $\mathrm{X}=\mathrm{O}^{2-}$ ligand made the triplet state rebound pathway less accessible by shifting the $\pi^{*}$ orbital towards a higher energy level.

The nature of the intermediates involved in $\mathrm{C}-\mathrm{H}$ oxidation was also debated and, in addition to the metal-oxo, metal-hydroxo complexes had been proposed as potential active species. ${ }^{63,64}$ Odile explored this possibility by extending the mechanistic studies towards the reactivity of the $\mathrm{Mn}^{\mathrm{v}} \mathrm{OH}$ moiety in both $\left[\mathrm{Mn}^{\mathrm{v}}(\mathrm{OH})(\mathrm{tHp})(\mathrm{OH})\right]^{+}$(i.e. the tautomer of $\left.\left[\mathrm{Mn}(\mathrm{O})(\mathrm{tHp})\left(\mathrm{OH}_{2}\right)\right]^{+}\right)$and $\mathrm{Mn}^{\mathrm{v}}(\mathrm{O})(\mathrm{tHp})(\mathrm{OH}){ }^{65} \mathrm{In}\left[\mathrm{Mn}^{\mathrm{v}}(\mathrm{OH})(\mathrm{tHp})(\mathrm{OH})\right]^{+}$, the ground state was a triplet in which a significant part of the spin density $(\rho=0.30 \alpha)$ was located over the hydroxo ligands. This radical character was strong enough as to enable $\mathrm{H}$-abstraction from toluene (Figure 7), which involved a low energy barrier of $4.8 \mathrm{kcal} \mathrm{mol}^{-1}$. In $\mathrm{Mn}^{\mathrm{v}}(\mathrm{O})(\mathrm{tHp})(\mathrm{OH})$, there was an interesting scenario in which both apical moieties, the oxo and the hydroxo, promoted H-abstraction. With a stronger 
radical character, the oxo clearly outcompeted the hydroxo, with energy barriers of 11.9 and 21.5 $\mathrm{kcal} \mathrm{mol}^{-1}$, respectively.

The $\mathrm{H}$-abstraction activity of the $\mathrm{Mn}^{\mathrm{v}} \mathrm{OH}$ moiety suggested that the $\mathrm{Mn}^{\mathrm{IV}} \mathrm{OH}$ intermediate of the classical rebound mechanism might also react in a similar manner, owing to its radical character (Figure 7). This opened the possibility of expanding the reactivity of these systems towards another highly regarded reaction - dehydrogenation (also referred to as desaturation, referring to the catalytic activity of desaturases). ${ }^{66}$ In collaboration with Crabtree and Brudvig, Odile explored the hydroxylation and dehydrogenation of substrates prone to undergo aromatization, with manganese-porphyrins. ${ }^{67}$ In the triplet state, $\mathrm{H}$-abstraction from 9,10-dihydrophenanthrene yielded a $\mathrm{Mn}^{\mathrm{IV}}(\mathrm{OH})(\mathrm{tpp})(\mathrm{Cl})$ (tpp = tetraphenylporphyrin) intermediate with a single unpaired electron in the $\mathrm{O}(p)$ orbital perpendicular to the $\mathrm{MnOH}$ plane. Due to the high degree of localization and directionality of this $\pi$-symmetry orbital, the radical, depending on how it was oriented, could react with either the other radical or the vicinal $\mathrm{C}-\mathrm{H}$ bond of the partially oxidized organic substrate (Figure 8). Both reactions involved a low and flat energy barrier $<1$ $\mathrm{kcal}^{\mathrm{mol}}{ }^{-1}$. In this framework, the outcome of the reaction could be controlled by two different mechanisms; 1) the orientation of the organic radical relative to the $\mathrm{Mn}^{\mathrm{IV}} \mathrm{OH}$ intermediate or, as supported by the calculations, 2) the $\mathrm{Mn}-\mathrm{OH}$ bond, which, by rotating in either clockwise or anticlockwise direction, could act as a switch between the two reactions. In the absence of the protein backbone found in desaturases, which can control both of these factors through a network of weak interactions, the experiments yielded a mixture of hydroxylation and dehydrogenation products. Remarkably, this became the first system based on manganese mimicking the catalytic activity of both hydroxylase and desaturase enzymes. 


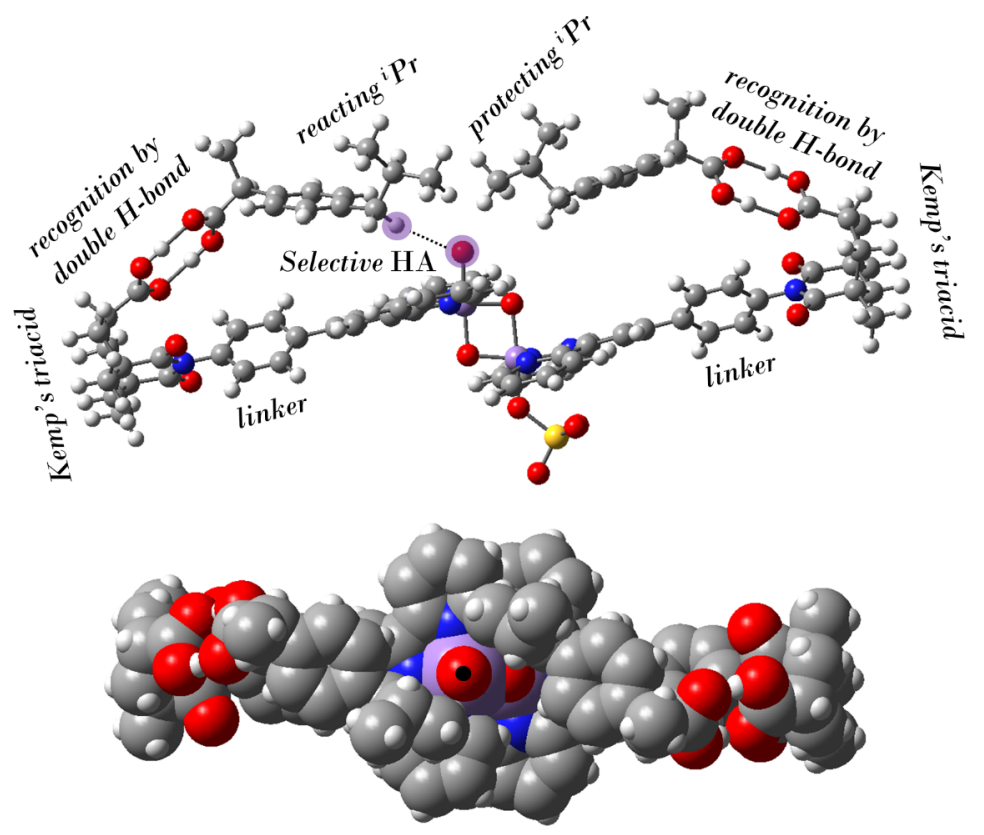

Figure 9. Different components of the dinuclear manganese catalyst in the selective $\mathrm{C}-\mathrm{H}$ oxidation of ibuprofen by molecular recognition. The space-filling model shows the oxyl ligand (dotted oxygen) buried below the ${ }^{i} \operatorname{Pr}$ groups of the two H-bound molecules of ibuprofen.

Following the idea of using manganese complexes as biomimetic systems, Odile worked on rationalizing the molecular recognition mechanism of the bimetallic catalyst reported by Crabtree and Brudvig in 2006. ${ }^{68}$ The DFT calculations provided a rational model explaining the selectivity observed for ibuprofen, which was preferentially oxidized at the benzylic position attached to the iso-propyl group (Figure 9). ${ }^{69}$ The carboxylic group of the substrate was recognized by the Kemp's triacid fragment through a double H-bond. In this way, the carboxylend of the molecule was protected whereas the ${ }^{i} \operatorname{Pr}$-end was exposed to the reactive center, forming a weak $\mathrm{C}-\mathrm{H} \cdots \mathrm{O}$ bond with the Mn-oxyl moiety. At the $\mathrm{H}$-abstraction transition state, the system was strained due to the larger shortening of the forming $\mathrm{O}-\mathrm{H}$ bond $(|\Delta \mathrm{d}|=1.26 \AA)$ 
relative to the elongation of the breaking $\mathrm{C}-\mathrm{H}$ bond $(|\Delta \mathrm{d}|=0.13 \AA)$. Nonetheless, the phenyl linker was flexible enough as to preserve the double- $\mathrm{H}$ bond recognition, without a major increase in the energy of the system, which yielded a low barrier of $6.5 \mathrm{kcal} \mathrm{mol}^{-1}$. The catalyst also promoted the non-selective oxidation of unrecognized substrate but, due to the lack of the double-H bond, these pathways involved higher energy profiles. Interestingly, the catalyst can recognize two substrate molecules in a simultaneous and cooperative manner. The substrate recognized at the shortest distance from the metal center reacts over the lowest barrier, whereas the other enhances selectivity by building steric bulk around the oxyl ligand, which hampers

$\mathrm{H}$-abstraction from unrecognized substrates. This steric blocking mechanism was supported by experiments proving the inhibition effect of tert-butyl benzoic acid.

\section{Catalytic Water Oxidation with Ir-Oxo Complexes}

The collaboration of Odile with Crabtree and Brudvig in the field of metal-catalyzed oxidations expanded to the oxygen-evolving reaction. ${ }^{70}$ In 2009, they reported the $\operatorname{Ir}\left(\mathrm{Cp}^{*}\right)(\mathrm{ppy})(\mathrm{Cl})$ (ppy = cyclometallated phenyl-pyridine) complex as a catalyst for the oxidation of water with CAN (cerium ammonium nitrate).$^{71}$ DFT calculations were used to characterize the electronic structure of $\operatorname{Ir}^{\mathrm{V}}(\mathrm{O})\left(\mathrm{Cp}^{*}\right)(\mathrm{ppy})$, which was postulated as active species. The antibonding $\pi^{*} \operatorname{Ir}(d)-\mathrm{O}(p)$ level contained two nearly degenerate orbitals $\left(\pi_{\mathrm{N}}{ }^{*}\right.$ and $\left.\pi_{\mathrm{C}}{ }^{*}\right)$ at the HOMO-LUMO limit (Figure 10). Both the singlet $\left(\pi_{\mathrm{N}} *\right)^{2}$ and triplet $\left(\pi_{\mathrm{N}} *\right)^{1}\left(\pi_{\mathrm{C}}\right)^{1}$ configurations were thermally accessible, with the low energy and partial occupation of these antibonding orbitals reinforcing the electrophilic character of the $\operatorname{Ir}^{\mathrm{v}} \mathrm{O}$ moiety. The key step of the mechanism, namely the formation of the $\mathrm{O}-\mathrm{O}$ bond by nucleophilic attack of water, was explored by considering two different proton acceptors: ${ }^{72}$ 1) the pyridine ring of the ppy ligand or 2) the oxo itself. In the first pathway, the protonation of the ppy ligand nitrogen broke the chelate yielding a high energy barrier of 36.0 $\mathrm{kcal} \mathrm{mol}^{-1}$. The second pathway was more favorable, but the barrier predicted by the calculations was also rather high $\left(32.2 \mathrm{kcal} \mathrm{mol}^{-1}\right)$. Nonetheless, the addition of one water molecule to the model assisting the proton transfer at the transition state lowered the barrier to $24.0 \mathrm{kcal} \mathrm{mol}^{-1}$. Subsequent studies on this system showed that the loss of the $\mathrm{Cp}^{*}$ ligand under catalytic conditions yielded more reactive species following similar mechanisms..$^{73,74}$ 
(A)
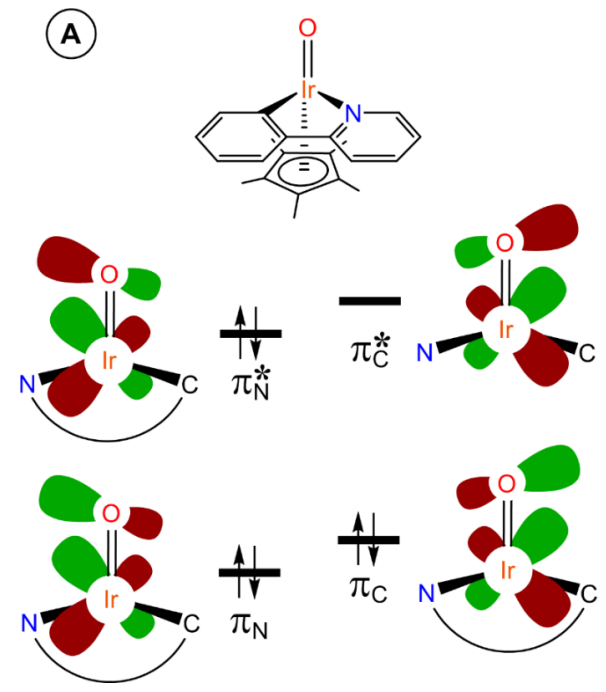

(B)
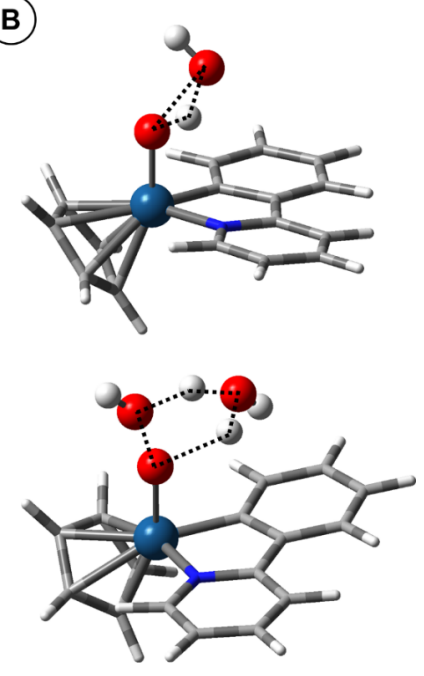

Figure 10. Key frontier orbitals in the $\operatorname{Ir}(\mathrm{V})$-oxo state of the iridium phenylpyridine catalyst (A) and transition states for $\mathrm{O}-\mathrm{O}$ bond formation by nucleophilic attack of water to the oxo ligand (B-top), including water-assisted proton transfer (B-bottom).

\section{Summary}

Odile Eisenstein has had a distinguished career where she has been instrumental in creating the field of computational homogeneous catalysis, and has made landmark contributions to some prominent challenges in areas such as $\sigma$-bond metathesis, olefin metathesis and water oxidation. We wish her a happy 70th birthday and good health and happiness for many more.

\section{AUTHOR INFORMATION}

\section{Corresponding Author}

*E-mail: fmaseras@iciq.es

\section{ORCID}


David Balcells: 0000-0002-3389-0543

Eric Clot: 0000-0001-8332-5545

Stuart A. Macgregor: 0000-0003-3454-6776

Feliu Maseras: 0000-0001-8806-2019

Lionel Perrin: 0000-0002-0702-8749

Notes

The authors declare no competing financial interest. 


\section{TOC Graphic}

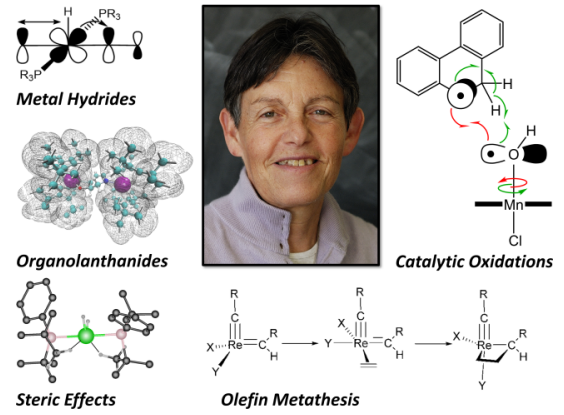




\section{References}

1 Anh, N. T.; Eisenstein, O. Theoretical Interpretation of 1,2 Asymmetric Induction. The Importance of Antiperiplanarity. Nouv. J. Chimie 1977, 1, 61-70.

2. Kubas, G. J.; Ryan, R. R.; Swanson, B. I.; Vergamini, P. J.; Wasserman, H. J. Characterization of the First Examples of Isolable Molecular Hydrogen Complexes, $\mathrm{M}(\mathrm{CO})_{3}\left(\mathrm{PR}_{3}\right)_{2}\left(\mathrm{H}_{2}\right)(\mathrm{M}=\mathrm{Mo}$ or W; $\mathrm{R}=\mathrm{Cy}$ or iPr). Evidence for a Side-on Bonded Dihydrogen ligand. J. Am. Chem. Soc. 1984, 106, $451-452$.

3. Jean, Y.; Eisenstein, O.; Volatron, F.; Maouche, B.; Sefta, F. Interaction Between $\mathrm{d}^{6} \mathrm{ML}_{5}$ Metal Fragments and Hydrogen: $\eta^{2}-\mathrm{H}_{2}$ vs. Dihydride Structure. J. Am. Chem. Soc. 1986, 108, 6587-6592.

4. Vandersluys, L. S.; Eckert, J.; Eisenstein, O.; Hall, J. H.; Huffman, J. C.; Jackson, S. A.; Koetzle, T. F.; Kubas, G. J.; Vergamini, P. J.; Caulton, K. G. An Attractive "Cis-Effect" of Hydride on Neighbor Ligands: Experimental and Theoretical Studies on the Structure and Intramolecular Rearrangements of $\mathrm{Fe}(\mathrm{H})_{2}\left(\eta^{2}-\mathrm{H}_{2}\right)\left(\mathrm{PEtPh}_{2}\right)_{3}$. J. Am. Chem. Soc. 1990, 112, 4831-4841.

5. Perutz, R. N.; Sabo-Etienne, S. The $\sigma$-CAM Mechanism: $\sigma$ Complexes as the Basis of $\sigma$-Bond Metathesis at Late-Transition-Metal Centers. Angew. Chem. Int. Ed. 2007, 46, 2578-2592.

6. Jackson, S. A.; Eisenstein, O. Long-Range Interaction Between Non-Bonded Hydrides: Attractive in the Case of Transition Metals? J. Am. Chem. Soc. 1990, 112, 7203-7207.

7. Chaudret, B.; Chung, G.; Eisenstein, O.; Jackson, S. A.; Lahoz, F. J.; Lopez, J. A. Preparation, XRay Molecular Structure, and Electronic Structure of the First 16-Electron Dihydrogen Complexes $\mathrm{RuH}\left(\mathrm{H}_{2}\right) \mathrm{X}\left(\mathrm{PCy}_{3}\right)_{2}$. J. Am. Chem. Soc. 1991, 113, 2314-2316.

8. Albinati, A.; Bakhmutov, V. I.; Caulton, K. G.; Clot, E.; Eckert, J.; Eisenstein, O.; Gusev, D. G.; Grushin, V. V.; Hauger, B. E.; Klooster, W. T.; Koetzle, T. F.; McMullan, R. K.; Oloughlin, T. J.; Pelissier, M.; Ricci, J. S.; Sigalas, M. P.; Vymenits, A. B. Reaction of $\mathrm{H}_{2}$ with $\mathrm{IrHCl}_{2} \mathrm{P}_{2}\left(\mathrm{P}=\mathrm{PiPr}_{3}\right.$ or $\left.\mathrm{P}^{\prime} \mathrm{Bu}_{2} \mathrm{Ph}\right)$ - Stereoelectronic Control of the Stability of Molecular $\mathrm{H}_{2}$ Transition-Metal Complexes. J. Am. Chem. Soc. 1993, 115, 7300-7312.

9. Rachidi, I. E.; Eisenstein, O.; Jean, Y. A Theoretical Study of the Possible Structures of $\mathrm{d}^{6} \mathrm{ML}_{5}$ Complexes. New J. Chem. 1990, 14, 671-677.

10. Riehl, J. F.; Jean, Y.; Eisenstein, O.; Pélissier, M. Theoretical Study of the Structures of ElectronDeficient $\mathrm{d}^{6} \mathrm{ML}_{5}$ Complexes. Importance of a $\pi$-Donating Ligand. Organometallics 1992, 11,729 737.

11. Lunder, D. M.; Lobkovsky, E. B.; Streib, W. E.; Caulton, K. G. Alkoxide $\pi$-Donation to Iridium(III). J. Am. Chem. Soc. 1991, 113, 1837-1838.

12. Johnson, T. J.; Folting, K.; Streib, W. E.; Martin, J. D.; Huffman, J. C.; Jackson, S. A.; Eisenstein, O.; Caulton, K. G. $\pi$-Stabilized, yet Reactive, Half-Sandwich $\mathrm{Cp} * \mathrm{Ru}\left(\mathrm{PR}_{3}\right) \mathrm{X}$ Compounds Synthesis, Structure, and Bonding. Inorg. Chem. 1995, 34, 488-499. 
13. Poulton, J. T.; Sigalas, M. P.; Folting, K.; Streib, W. E.; Eisenstein, O.; Caulton, K. G. $\mathrm{RuHX}(\mathrm{CO})\left(\mathrm{PR}_{3}\right)_{2}-\mathrm{Can} v_{\mathrm{CO}}$ be a Probe for the Nature of the Ru-X Bond? Inorg. Chem. 1994, 33, $1476-1485$.

14. Heyn, R. H.; Macgregor, S. A.; Nadasdi, T. T.; Ogasawara, M.; Eisenstein, O.; Caulton, K. G. Is $\pi$ Donation the Only Way? Unprecedented Unsaturated Ru(II) Species Devoid of $\pi$-Donor Ligands. Inorg. Chim. Acta 1997, 259, 5-26.

15. Ogasawara, M.; Huang, D. J.; Streib, W. E.; Huffman, J. C.; GallegoPlanas, N.; Maseras, F.; Eisenstein, O.; Caulton, K. G. $\mathrm{RuX}(\mathrm{CO})(\mathrm{NO}) \mathrm{L}_{2}$ and $\mathrm{Ru}(\mathrm{CO})(\mathrm{NO}) \mathrm{L}_{2}{ }^{+}: \mathrm{Ru}(0)$ or $\mathrm{Ru}(\mathrm{II})$ or in between? J. Am. Chem. Soc. 1997, 119, 8642-8651.

16 Maseras, F.; Eisenstein, O. Opposing Steric and Electronic Contributions in $\mathrm{OsCl}_{2} \mathrm{H} 2\left(\mathrm{P}^{\mathrm{i}} \mathrm{Pr}_{3}\right)_{2}$. A theoretical study of an unusual structure. New J. Chem. 1998, 22, 5-9.

17 Gusev, D. G.; Kuhlman, R.; Rambo, J. R.; Berke, H.; Eisenstein, O.; Caulton, K. G. Structural and Dynamic Properties of $\mathrm{OsH}_{2} \mathrm{X}_{2} \mathrm{~L}_{2}\left(\mathrm{X}=\mathrm{Cl}, \mathrm{Br}, \mathrm{I} ; \mathrm{L}=\mathrm{P}^{\mathrm{P}} \mathrm{Pr}_{3}\right)$ Complexes: Interconversion between Remarkable Non-Octahedral Isomers. J. Am. Chem. Soc. 1995, 117, 281-292.

18 Maseras, F.; Morokuma, K. A New "Ab Initio + Molecular Mechanics" Geometry Optimization Scheme of Equilibrium Structures and Transition States. J. Comput. Chem. 1995, 16, 1170-1179.

19 Ujaque, G.; Maseras, F.; Eisenstein, O. Different van der Waals Radii for Organic and Inorganic Halogen Atoms: A Significant Improvement in IMOMM Performance. Theor. Chem. Acc. 1997, $96,146-150$.

20 Ujaque, G., Maseras, F.; Eisenstein, O.; Liable-Sands, L.; Rheingold, A. L.; Yao, W.; Crabtree, R. H. Breaking an Electronically Preferred Symmetry by Steric Effects in a Series of [Ir(biph)X(QR3)2] Compounds (X= Cl or I, Q= P or As). New J. Chem. 1998, 22, 1493-1498.

21 Ogasawara, M.; Macgregor, S. A.; Streib, W. E.; Folting, K.; Eisenstein, O.; Caulton, K. G. Characterization and Reactivity of an Unprecedented Unsaturated Zero-Valent Ruthenium Species: Isolable, Yet Highly Rective. J. Am. Chem. Soc. 1996, 118, 10189-10199.

22 Huang, D.; Streib, W. E.; Eisenstein, O.; Caulton, K. G. [Ru(Ph) $\left.(\mathrm{CO})\left(\mathrm{P}^{\prime} \mathrm{Bu} \mathrm{L}_{2} \mathrm{Me}\right)_{2}\right]^{+}$: A Unique 14Electron $\mathrm{Ru}^{\mathrm{II}}$ Complex with Two Agostic Interactions. Angew. Chem. Int. Ed. 1997, 36, 20042006.

23 Gottschalk-Gaudig, T.; Huffman, J. C.; Caulton, K. G.; Gérard, H.; Eisenstein, O. Solution and Solid-State Structure of $\mathrm{Ru}(\mathrm{CO})_{2}\left({ }^{\prime} \mathrm{Bu}_{2} \mathrm{PC}_{2} \mathrm{H}_{4} \mathrm{P}^{\prime} \mathrm{Bu}_{2}\right)$ : Square Planar and Monomeric? J. Am. Chem. Soc. 1999, 121, 3242-3243.

24 Ujaque, G.; Cooper, A. C.; Maseras, F.; Eisenstein, O.; Caulton, K. G. Computational Evidence of the Importance of Substituent Bulk on Agostic Interactions in $\operatorname{Ir}(\mathrm{H})_{2}\left(\mathrm{P}^{\prime} \mathrm{Bu}_{2} \mathrm{Ph}\right)_{2}{ }^{+}$. J. Am. Chem. Soc. 1998, 120, 361--365. 
25 Cooper, A. C.; Clot, E.; Huffman, J. C.; Streib, W. E.; Maseras, F.; Eisenstein, O.; Caulton, K. G. Computational and Experimental Test of Steric Influence on Agostic Interactions: A Homologous Series for $\operatorname{Ir}(\mathrm{III})$. J. Am. Chem. Soc. 1999, 121, 97-106.

26 Ogasawara, M.; Maseras, F.; Gallego-Planas, N.; Streib, W. E.; Eisenstein, O.; Caulton, K. G. Unexpecte Coexistence of Isomeric Forms and Unusual Structures of $\mathrm{Ru}(\mathrm{CO})_{2} \mathrm{~L}_{3}$. Inorg. Chem. 1996, 35, 7468-7469.

27 Ogasawara, M.; Maseras, F.; Gallego-Planas, N.; Kawamura, K.; Ito, K.; Toyota, K.; Streib, W. E.; Komiya, S.; Eisenstein, O.; Caulton, K. G. Competition between Steric and Electronic Control of Structure in $\mathrm{Ru}(\mathrm{CO})_{2} \mathrm{~L}_{2} \mathrm{~L}$ ' Complexes. Organometallics 1997, 16, 1979-1993.

28 Bianchini, C.; Caulton, K. G.; Chardon, C.; Eisenstein, O.; Folting, K.; Johnson, T. J.; Meli, A.; Peruzzini, M.; Rauscher, D. J.; Streib, W. E.; Vizza, F. An $\eta^{4}$-Benzene Species Mediates Acetylene Cyclotrimerization. J. Am. Chem. Soc. 1991, 113, 5127-5129.

29 Bianchini, C.; Caulton, K. G.; Chardon, C.; Doublet, M.-L.; Eisenstein, O.; Jackson, S. A.; Johnson, T. J.; Meli, A.; Peruzzini, M.; Streib, W. E.; Vacca, A.; Vizza, F. Mechanism of Acetylene Cyclotrimerization Catalyzed by the fac- $\mathrm{IrP}_{3}{ }^{+}$Fragment: Relationship between Fluxionality and Catalysis. Organometallics 1994, 13, 2010-2023.

30 Bosque, R.; Clot, E.; Fantacci, S.; Maseras, F.; Eisenstein, O.; Perutz, R. N.; Renkema, K. B.; Caulton, K. G. Inertness of the Aryl-F Bond toward Oxidative Addition to Osmium and Rhodium Complexes: Thermodynamic or Kinetic Origin? J. Am. Chem. Soc. 1998, 120, 12634-12640.

31 Clot, E.; Eisenstein, O.; Naseralla, J.; Macgregor, S. A.; Mcgrady, J. E.; Perutz, R. N. C-F and C-H Bond Activation of Fluorobenzes and Fluoropyridines at Transition Metal Centers: How Fluorine Tips the Scales. Acc. Chem. Res. 2011, 44, 333-348.

32 Eisenstein, O.; Milani, J.; Perutz, R. N. Selectivity of C-H Activation and Competition between CH and C-F Bond Activation at Fluorocarbons. Chem. Rev. 2017, 117, 8710-87153.

33 Lockwood, M. A.; Fanwick, P. E.; Eisenstein, O.; Rothwell, I. P. Mechanistic Studies of the Facile Four-Electron Reduction of Azobenzene at a Single Tungsten Metal Center. J. Am. Chem. Soc. 1996, 118, 2762-2763.

34 Maseras, F.; Lockwood, M. A.; Eisenstein, O.; Rothwell, I. P. Four-Electron Reduction of Diazo Compounds at a Single Tungsten Metal Center: A Theoretical Study of the Mechanism. J. Am. Chem. Soc. 1998, 120, 6598-6602.

35 Maron, L.; Eisenstein, O. Do f Electrons Play a Role in the Lanthanide-Ligand Bonds? A DFT Study of $\operatorname{Ln}\left(\mathrm{NR}_{2}\right)_{3} ; \mathrm{R}=\mathrm{H}, \mathrm{SiH}_{3}$. J. Phys. Chem. A 2000, 104, 7140-7143.

36 Kefalidis, C. E.; Castro, L.; Perrin, L.; Del Rosal, I.; Maron, L. New Perspectives in Organolanthanide Chemistry from Redox to Bond Metathesis: Insights from Theory. Chem. Soc. Rev. 2016, 45, 2516-2543.

37 Maron, L.; Eisenstein, O. DFT Study of $\mathrm{H}-\mathrm{H}$ Activation by $\mathrm{Cp}_{2} \mathrm{LnH}_{\mathrm{d}}^{0}$ Complexes. J Am Chem Soc. 2001, 123, 1036-1039. 
38 Maron, L.; Perrin, L.; Eisenstein, O. DFT Study of $\mathrm{CH}_{4}$ Activation by d(0) $\mathrm{Cl}_{2} \mathrm{LnZ}\left(\mathrm{Z}=\mathrm{H}, \mathrm{CH}_{3}\right)$ Complexes. J. Chem. Soc. - Dalton Trans. 2002, 534-539.

39 Perrin, L.; Maron, L.; Eisenstein, O. A DFT Study of $\mathrm{SiH}_{4}$ Activation by $\mathrm{Cp}_{2}$ LnH. Inorg. Chem. $200241,4355-4362$

40 Perrin, L.; Eisenstein, O.; Maron, L. Chemoselectivity in $\sigma$ Bond Activations by Lanthanocene Complexes from a DFT Perspective: Reactions of $\mathrm{Cp}_{2} \mathrm{LnR}\left(\mathrm{R}=\mathrm{CH}_{3}, \mathrm{H}, \mathrm{SiH}_{3}\right)$ with $\mathrm{SiH}_{4}$ and $\mathrm{CH}_{3}-$ $\mathrm{SiH}_{3}$. New J. Chem. 2007, 31, 549-555.

41 Perrin, L.; Maron, L.; Eisenstein, O.; Tilley, T. D. Bond Activations of $\mathrm{PhSiH}_{2}$ by $\mathrm{Cp}_{2} \mathrm{SmH}$ : A Mechanistic Investigation by the DFT method. Organometallics 2009, 28, 3767-3775.

42 Maron, L.; Perrin, L.; Eisenstein, O. $\mathrm{CF}_{4}$ Defluorination by $\mathrm{Cp}_{2} \mathrm{Ln}-\mathrm{H}$ : a DFT Study. Dalton Trans. 2003, 4313-4318.

43 Werkema, E. L.; Messines, E.; Perrin, L.; Maron, L.; Eisenstein, O.; Andersen, R. A. Hydrogen for Fluorine Exchange in $\mathrm{CH}_{4-\mathrm{x}} \mathrm{F}_{\mathrm{x}}$ by Monomeric [1,2,4-( $\left.\left.\mathrm{Me}_{3} \mathrm{C}\right)_{3} \mathrm{C}_{5} \mathrm{H}_{2}\right]_{2} \mathrm{CeH}$ : Experimental and Computational Studies. J. Am. Chem. Soc. 2005, 127, 7781-7795.

44 Maron, L.; Werkema, E. L.; Perrin, L.; Eisenstein, O.; Andersen, R. A. Hydrogen for fluorine exchange in $\mathrm{C}_{6} \mathrm{~F}_{6}$ and $\mathrm{C}_{6} \mathrm{~F}_{5} \mathrm{H}$ by monomeric $\left[1,3,4-\left(\mathrm{Me}_{3} \mathrm{C}_{3} \mathrm{C}_{5} \mathrm{H}_{2}\right]_{2} \mathrm{CeH}\right.$ : Experimental and computational studies. J. Am. Chem. Soc. 2005, 127, 279-292.

45 Raynaud, C.; Perrin, L.; Maron, L. A DFT Study of Stannane Dehydrocoupling Catalyzed by $\mathrm{Cp}_{2} \mathrm{LaH}$. Organometallics 2006, 25, 3143-3151.

46 Guihaume, J.; Raynaud, C.; Eisenstein, O.; Perrin, L.; Maron, L.; Don Tilley, T. Facile Interconversion of $\left[\mathrm{Cp}_{2}(\mathrm{Cl}) \mathrm{Hf}\left(\mathrm{SnH}_{3}\right)\right]$ and $\left[\mathrm{Cp}_{2}(\mathrm{Cl}) \mathrm{Hf}(\mu-\mathrm{H}) \mathrm{SnH}_{2}\right]$ : DFT Investigations of Hafnocene Stannyl Complexes as Masked Stannylenes. Angew. Chem. Int. Ed. 2010, 49, 18161819.

47 Perrin, L.; Werkema, E. L.; Eisenstein, O.; Andersen, R. A. Two [1,2,4-( $\left(\mathrm{Me}_{3} \mathrm{C}_{3} \mathrm{C}_{5} \mathrm{H}_{2}\right]_{2} \mathrm{CeH}$ Molecules are Involved in the Hydrogenation of Pyridine to Piperidine as Shown by Experiments and Calculations. Inorg. Chem. 2014, 53, 6361-6373.

48 Chabanas, M.; Baudouin, A.; Copéret, C.; Basset, J.-M. A Highly Active Well-Defined Rhenium Heterogeneous Catalyst for Olefin Metathesis Prepared via Surface Organometallic Chemistry. $J$. Am. Chem. Soc. 2001, 123, 2062-2063.

49 Toreki, R.; Vaughan, G. A.; Schrock, R. R.; Davis, W. M. Metathetical Reactions of Re(VII) Alkylidene-Alkylidyne Complexes of the Type $\mathrm{Re}\left(\mathrm{CR}^{\prime}\right)(\mathrm{CHR})\left[\mathrm{OCMe}\left(\mathrm{CF}_{3}\right)_{2}\right]_{2}\left(\mathrm{R}^{\prime}=\mathrm{CMe}_{3}\right.$ or $\mathrm{CMe}_{2} \mathrm{Ph}$ ) with Terminal and Internal Olefins. J. Am. Chem. Soc. 1993, 115, 127-137.

50 Solans-Monfort, X.; Clot, E.; Copéret, C.; Eisenstein, O. Understanding Structural and Dynamic Properties of Well-Defined Rhenium-Based Olefin Metathesis Catalysts, $\operatorname{Re}(\equiv \mathrm{CR})(=\mathrm{CHR})(\mathrm{X})(\mathrm{Y})$ from DFT and QM/MM Calculations. Organometallics 2005, 24, 1586-1597. 
51 Solans-Monfort, X.; Clot, E.; Copéret, C.; Eisenstein, O. d ${ }^{0}$ Re-based Olefin Metathesis Catalysts, $\operatorname{Re}(\equiv \mathrm{CR})(=\mathrm{CHR})(\mathrm{X})(\mathrm{Y})$ : The Key Role of $\mathrm{X}$ and $\mathrm{Y}$ Ligands for Efficient Active Sites. J. Am. Chem. Soc. 2005, 127, 14015-14025.

52 Poater, A.; Solans-Monfort, X.; Clot, E.; Copéret, C.; Eisenstein, O. Understanding d ${ }^{0}$-Olefin Metathesis-Catalysts: Which Metal, Which Ligand? J. Am. Chem. Soc. 2007, 129, 8207-8216.

53 Sattely, E. S.; Meek, S.J.; Malcolmson, S.J.; Schrock, R. R.; Hoveyda, A. H. Design and Stereoselective Preparation of a New Class of Chiral Olefin Metathesis Catalysts and Applications to Enantioselective Synthesis of Quebrachamine: Catalyst Development Inspired by Natural Product Synthesis. J. Am. Chem. Soc. 2009, 131, 943-953.

54 Leduc, A.-M.; Salameh, A.; Soulivong, D.; Chabanas, M.; Basset, J.-M.; Copéret, C.; SolansMonfort, X.; Clot, E.; Eisenstein, O.; Böhm, V. P. W.; Röper, M. $\beta$-H Transfer from the Metallacyclobutane: A Key Step in the Deactivation and Byproduct Formation for the WellDefined Silica-Supported Rhenium Alkylidene Alkene Metathesis Catalyst. J. Am. Chem. Soc. 2008, 130, 6288-6297.

55 Solans-Monfort, X.; Copéret, C.; Eisenstein, O. Shutting Down Secondary Reaction Pathways : The Essential Role of the Pyrrolyl Ligand in Improving Silica Supported d ${ }^{0}-M_{4}$ Alkene Metathesis Catalysts from DFT Calculations. J. Am. Chem. Soc. 2010, 132, 7750-7757.

56 Gordon, C. P.; Yamamoto, K.; Liao, W. C.; Allouche, F.; Andersen, R. A.; Copéret, C.; Raynaud, C.; Eisenstein, O. Metathesis Activity Encoded in the Metallacyclobutane Carbon-13 NMR Chemical Shift Tensors. ACS Central Sci. 2017, 3, 759-768.

57 Balcells, D.; Raynaud, C.; Crabtree, R. H.; Eisenstein, O. The Rebound Mechanism in Catalytic C$\mathrm{H}$ Oxidation by $\mathrm{MnO}(\mathrm{tpp})(\mathrm{Cl})$ from DFT Studies: Electronic Nature of the Active Species. Chem. Commun. 2008, 744-746.

58 Meunier, B. Metalloporphyrins as Versatile Catalysts for Oxidation Reactions and Oxidative DNA Cleavage. Chem. Rev. 1992, 92, 1411-1456.

59 Huang, X.; Groves, J. T. Oxygen Activation and Radical Transformations in Heme Proteins and Metalloporphyrins. Chem. Rev. 2018, 118, 2491-2553.

60 Shaik, S.; Hirao, H.; Kumar, D. Reactivity of High-Valent Iron-Oxo Species in Enzymes and Synthetic Reagents: A Tale of Many States. Acc. Chem. Res. 2007, 40, 532-542.

61 Jin, N.; Ibrahim, M-; Spiro, T. G.; Groves, J. T. Trans-dioxo Manganese(V) Porphyrins. J. Am. Chem. Soc. 2007, 129, 12416-12417.

62 Balcells, D.; Raynaud, C.; Crabtree, R. H.; Eisenstein, O. A Rational Basis for the Axial Ligand Effect in $\mathrm{C}-\mathrm{H}$ Oxidation by $[\mathrm{MnO}$ (porphyrin $)(\mathrm{X})]^{+}\left(\mathrm{X}=\mathrm{H}_{2} \mathrm{O}, \mathrm{OH}^{-}, \mathrm{O}_{2}^{-}\right)$from a DFT Study. Inorg. Chem. 2008, 47, 10090-10099. 
63 Bernadou, J.; Fabiano, A.-S.; Robert, A.; Meunier, B. "Redox Tautomerism" in High-Valent Metaloxo-aquo Complexes. Origin of the Oxygen Atom in Epoxidation Reactions Catalyzed by WaterSoluble Metalloporphyrins. J. Am. Chem. Soc. 1994, 116, 9375-9376.

64 Gao, H.; Groves, J. T. Fast Hydrogen Atom Abstraction by a Hydroxo Iron(III) Porphyrazine. J. Am. Chem. Soc. 2017, 139, 3938-3941.

65 Balcells, D.; Raynaud, C.; Crabtree, R. H.; Eisenstein, O. C-H Oxidation by Hydroxo Manganese(V) Porphyrins: a DFT Study. Chem. Commun. 2009, 1772-1774.

66 Savile, C. K.; Fabriàs, G.; Buist, P. H. Dihydroceramide $\Delta^{4}$ Desaturase Initiates Substrate Oxidation at C-4. J. Am. Chem. Soc. 2001, 123, 4382-4385.

67 Hull, J. F.; Balcells, D.; Sauer, E. L. O.; Raynaud, C.; Brudvig, G. W.; Crabtree, R. H.; Eisenstein, O. Manganese Catalysts for C-H Activation: An Experimental/Theoretical Study Identifies the Stereoelectronic Factor that Controls the Switch between Hydroxylation and DesaturationPpathways. J. Am. Chem. Soc. 2010, 132, 7605-7616.

68 Das, S.; Incarvito, C. D.; Crabtree, R. H.; Brudvig, G. W. Molecular Recognition in the Selective Oxygenation of Saturated C-H Bonds by a Dimanganese Catalyst. Science 2006, 312, 1941-1943.

69 Balcells, D.; Moles, P.; Blakemore, J. D.; Raynaud, C.; Brudvig, G. W.; Crabtree, R. H.; Eisenstein, O. Molecular Recognition in Mn-catalyzed C-H Oxidation. Reaction Mechanism and Origin of Selectivity from a DFT Perspective. Dalton Trans. 2009, 5989-6000.

70 Blakemore, J. D.; Crabtree, R. H.; Brudvig, G. W. Molecular Catalysts for Water Oxidation. Chem. Rev. 2015, 115, 12974-13005.

71 Hull, J. F.; Balcells, D.; Blakemore, J. D.; Incarvito, C. D.; Eisenstein, O.; Brudvig, G. W.; Crabtree, R. H. Highly Active and Robust Cp* Iridium Complexes for Catalytic Water Oxidation. J. Am. Chem. Soc. 2009, 131, 8730-8731.

72 Blakemore, J. D.; Schley, N. D.; Balcells, D.; Hull, J. F.; Olack, G. W.; Incarvito, C. D.; Eisenstein, O.; Brudvig, G. W.; Crabtree, R. H. Half-sandwich Iridium Complexes for Homogeneous WaterOxidation Catalysis. J. Am. Chem. Soc. 2010, 132, 16017-16029.

73 Hintermair, U.; Sheehan, S. W.; Parent, A. R.; Ess, D. H.; Richens, D. T.; Vaccaro, P. H.; Brudvig, G. W.; Crabtree, R. H. Precursor Transformation during Molecular Oxidation Catalysis with Organometallic Iridium Complexes. J. Am. Chem. Soc. 2013, 135, 10837-10851.

74 Ingram, A. J.; Wolk, A. B.; Flender, C.; Zhang, J.; Johnson, C. J.; Hintermair, U.; Crabtree, R. H.; Johnson, M. A.; Zare, R. N. Modes of Activation of Organometallic Iridium Complexes for Catalytic Water and C-H Oxidation. Inorg. Chem. 2014, 53, 423-433. 